\title{
Micro- and nanosensors for detecting blood pathogens and biomarkers at different points of sepsis care
}

\author{
Alejandra Alba-Patiño $0^{1,3} \cdot$ Andreu Vaquer ${ }^{1,3} \cdot$ Enrique Barón $^{1} \cdot$ Steven M. Russell ${ }^{1}$ Marcio Borges ${ }^{1,2}$. \\ Roberto de la Rica ${ }^{1}$
}

Received: 19 August 2021 / Accepted: 26 December 2021 / Published online: 26 January 2022

(c) The Author(s), under exclusive licence to Springer-Verlag GmbH Austria, part of Springer Nature 2022

\begin{abstract}
Severe infections can cause a dysregulated response leading to organ dysfunction known as sepsis. Sepsis can be lethal if not identified and treated right away. This requires measuring biomarkers and pathogens rapidly at the different points where sepsis care is provided. Current commercial approaches for sepsis diagnosis are not fast, sensitive, and/or specific enough for meeting this medical challenge. In this article, we review recent advances in the development of diagnostic tools for sepsis management based on micro- and nanostructured materials. We start with a brief introduction to the most popular biomarkers for sepsis diagnosis (lactate, procalcitonin, cytokines, C-reactive protein, and other emerging protein and non-protein biomarkers including miRNAs and cell-based assays) and methods for detecting bacteremia. We then highlight the role of nano- and microstructured materials in developing biosensors for detecting them taking into consideration the particular needs of every point of sepsis care (e.g., ultrafast detection of multiple protein biomarkers for diagnosing in triage, emergency room, ward, and intensive care unit; quantitative detection to de-escalate treatment; ultrasensitive and culture-independent detection of blood pathogens for personalized antimicrobial therapies; robust, portable, and web-connected biomarker tests outside the hospital). We conclude with an overview of the most utilized nano- and microstructured materials used thus far for solving issues related to sepsis diagnosis and point to new challenges for future development.
\end{abstract}

Keywords Cytokine $\cdot$ Blood pathogen $\cdot$ Biosensor $\cdot$ Infection $\cdot$ Sepsis care $\cdot$ Procalcitonin $\cdot$ Lactate $\cdot$ Bacteremia

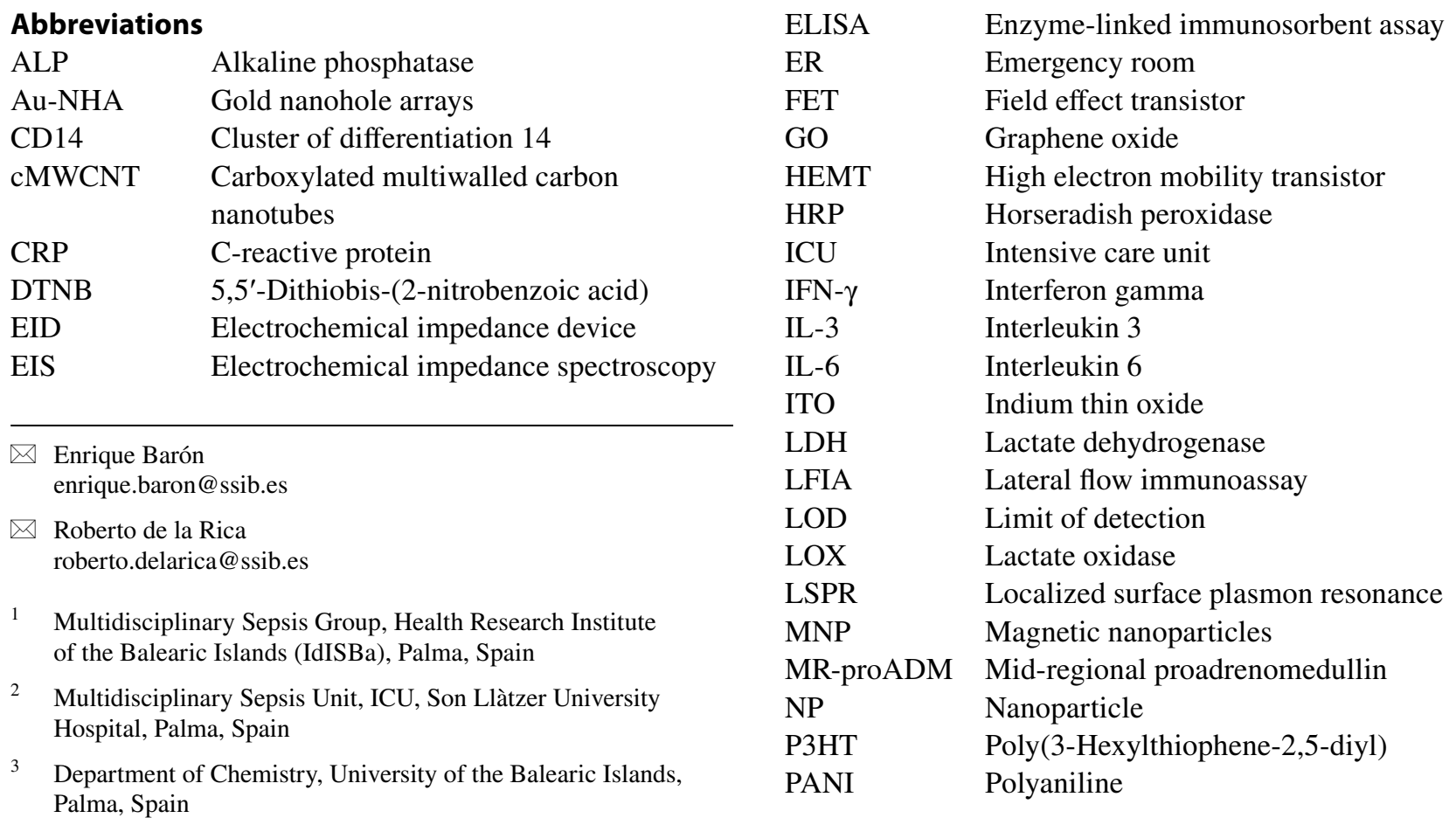




$\begin{array}{ll}\text { PCT } & \text { Procalcitonin } \\ \text { PDA } & \text { Poly(Dopamine) } \\ \text { PDMS } & \text { Polydimethylsiloxane } \\ \text { PEDOT } & \text { Poly(3,5-Dioxoethylthiophene) } \\ \text { PGE } & \text { Pencil graphite electrode } \\ \text { PMMA } & \text { Poly(Methyl methacrylate) } \\ \text { PMPC } & \begin{array}{l}\text { Poly(2-Methacryloyloxyethyl } \\ \text { phosphorylcholine) }\end{array} \\ & \text { Point of care } \\ \text { PoC } & \text { Polystyrene } \\ \text { PS } & \text { Polyvynil chloride } \\ \text { PVC } & \text { Quantum dots } \\ \text { QD } & \text { Regenerated cellulose } \\ \text { RC } & \text { Surface-enhanced Raman scattering } \\ \text { SERS } & \text { Non-lethal systemic inflammatory } \\ \text { SIRS } & \text { response syndrome } \\ \text { SOFA score } & \text { Sequential organ failure assessment score } \\ \text { SPA } & \text { Staphylococcal protein A } \\ \text { SPE } & \text { Screen-printed carbon electrode } \\ \text { SPR } & \text { Surface plasmon resonance } \\ \text { sTREM-1 } & \text { Soluble Triggering Receptor Expressed by } \\ \text { suPAR } & \text { Myeloid cells 1 } \\ & \text { Soluble urokinase-type plasminogen acti- } \\ \text { TMB } & \text { vator receptor } \\ \text { TNF- } \alpha & 3,3^{\prime}, 5,5^{\prime} \text {-Tetramethylbenzidine } \\ & \text { Tumor necrosis factor } \alpha\end{array}$

\section{Introduction}

According to a recent report, about $20 \%$ of the world deaths in 2019 were caused by sepsis [1]. Sepsis is an exaggerated host response to an infection that can lead to the dysfunction of several vital organs and eventually to death if not treated in a timely manner [2]. The International Surviving Sepsis Campaign recommends administering intravenous antibiotics within the first hour of recognizing sepsis, since mortality rates sharply increase afterwards [3, 4]. However, several challenges make sepsis difficult to diagnose and treat at an early stage. For starters, there is no ideal gold standard for sepsis diagnosis. Detecting pathogens in the bloodstream (bacteremia) through blood culture is considered definitive proof of sepsis in patients with compatible clinical criteria. However, even though this approach has an ultralow limit of detection (a few pathogens in a sample consisting of $30-50 \mathrm{~mL}$ of blood), it only diagnoses sepsis correctly in $20-40 \%$ of cases [5]. In other words, the diagnostic specificity is very high, but the sensitivity is very low. Furthermore, sepsis is strongly time-dependent. It usually starts as a nonlethal systemic inflammatory response syndrome (SIRS) that progresses to multiorgan dysfunction [5]. SIRS can be originated by an uncomplicated infection as well as by other pathologies such as trauma or cancer, which do not require intravenous antibiotics. However, patients with infectionrelated SIRS can rapidly evolve to sepsis, and therefore, it is imperative to identify them as soon as possible and monitor their progress to avoid poor outcomes. Finally, sepsis is more frequent in immunocompromised individuals such as cancer patients or the elderly [6]. These populations often present confounding factors such as chronic inflammation and dysregulated body temperature that make it even harder to identify sepsis.

Measuring alterations of the host response to an infection is a faster alternative to blood culture for guiding the diagnosis of sepsis. Indeed, many diagnosing algorithms include measurements of serum biomarkers, which in addition to vital constants and epidemiological data, can be used to predict sepsis cases [2]. Yet, biomarker measurements can also be misleading for sepsis diagnosis. On the one hand, biomarker levels fluctuate as sepsis progresses and these timedependent variations in concentration are different for each biomarker [7]. This means that biomarker measurements must be rapid to correctly reflect the patient status, and that more than one biomarker should be measured in order to identify sepsis independently of disease stage. On the other hand, most biomarkers used for sepsis diagnosis are inflammation biomarkers whose levels may be altered by other conditions such as trauma, surgeries, cancer, or nephropathies. Thus, biomarker levels should always be interpreted in the context of a personalized assessment that takes into consideration all the variables of each particular patient.

The abovementioned issues could be greatly alleviated by using biosensors implementing micro- and nanostructured components for the frequent, rapid testing of multiple sepsis biomarkers [8, 9]. Frequent testing of at-risk patients with rapid methods could reveal time-dependent variations in biomarkers related to the onset of sepsis. This requires inexpensive mass-produced tests, for example, electrochemical biosensors fabricated with CMOS-compatible procedures, or disposable nanoparticle-based biosensors made of paper. Measuring multiple biomarkers would increase the specificity of the diagnosis, which can otherwise be confounded by timing and comorbidities. Micro- and nanoelectrode arrays are ideal for meeting this challenge because they allow fitting multiple sensors into a compact design. Since time is of the essence, biosensors for sepsis diagnosis should be sensitive, afford a high positive predictive value, and provide results at the bedside [9]. The outstanding physical properties of nanomaterials such as plasmonic nanoparticles, quantum dots, and graphene make them ideal candidates for boosting the sensitivity and reducing the time-to-diagnosis. Decentralized measurements are also important because sepsis is managed in a wide variety of healthcare settings, from ambulances to the emergency room, medical and surgical wards, or the intensive care unit (ICU). This means that tools for sepsis diagnosis should be made widely available, 
and that the results obtained at each step of the healthcare chain should be collated and shared with other healthcare workers. Compact devices are required to tackle this issue, for example, microelectrodes that are fully integrated with the circuitry and optical biosensors combining plasmonic or fluorescent nanoparticles with smartphone readouts. Since measurements are to be performed by a frontline healthcare worker at the bedside, the biosensors should be easy to use. Microfluidic devices can reduce the steps required for completing the assay, thus making them more user friendly for bedside diagnostics. Furthermore, biosensor readers must be portable, and if possible inexpensive, in order to ensure their widespread implementation in different healthcare scenarios. While in many countries sepsis is primarily managed in well-equipped hospitals, in resource-constrained areas, such infrastructure is unavailable. Unfortunately, sepsis has a higher incidence in developing countries, which makes finding global solutions for sepsis management highly relevant [1].

In this manuscript, we introduce the main biosensor configurations used for diagnosing sepsis. Subsequently, we introduce some of the most promising biomarker candidates which, alone or combined, have been proposed for diagnosing sepsis. Then, we critically review commercial tests and the recent literature for biosensors based on micro- and nanostructured materials aimed at measuring biomarkers and circulating pathogens, and propose different points of the healthcare chain where they could improve sepsis care. Methods for pathogen identification samples other than blood and for determining their susceptibility to antibiotics have been recently reviewed elsewhere [10-12]. We finalize by discussing the relevance of micro- and nanostructured materials for developing sepsis biosensors and proposing future advancements for the field.

\section{Biosensor configuration}

Biosensors are a subcategory of chemical sensors that utilize a biomolecule, cell, organism, or biological mimic in order to quantify a target analyte. The most common biosensor configuration involves modifying a transducer with a biorecognition element, which captures the analyte with high selectivity and specificity. This triggers a change in a physical property that is measured by the transducer.

Electrochemical methods monitor the reaction kinetics of an electroactive species at the electrode/solution interface by measuring the current, voltage, or impedance, as recently reviewed by others [13]. Microstructured electrochemical sensors can be manufactured using well-established methods for microchip fabrication [14]. This makes it easy to fabricate sensor arrays, wearable devices, and ultramicroelectrodes integrated in microfluidic platforms for point-of-care diagnostics. They also exhibit excellent sensitivity and reproducibility. Their performance can be greatly improved by incorporating nanomaterials such as gold, copper [15], platinum [16, 17], Prussian blue or zinc nanoparticles [18], carbon nanodots [19], quantum dots [20], magnetic beads [21-24], graphene [25, 26], graphene oxide [27-30], and carbon nanotubes $[15,27,31]$. The large surface area afforded by nanomaterials facilitates the capture of the target at the electrode/solution interface and increases currents.

Optical biosensors measure the variation of an optical property (e.g., chemiluminescence, absorbance, fluorescence) triggered by the biorecognition reactions, as discussed in detail in previous works [32, 33]. Two configurations of optical biosensors have gained great momentum for diagnosing infectious diseases. The first configuration is the lateral flow test, which includes a pumpless microfluidic system with colorimetric signals that can be evaluated by eye [34]. This makes them useful for the rapid evaluation of targets without using auxiliary instrumentation, for instance, for the rapid detection of SARS-CoV-2 antigens or HIV antibodies. The second configuration leverages the camera of a smartphone to read signals. This makes it possible to perform quantitative measurements using a piece of instrumentation that is easily available at any point of healthcare [35]. Nanostructured materials have revolutionized the field of optical sensors thanks to the outstanding physical properties afforded by the nanoscale morphology. For example, the intense coloration seen in suspensions of noble metal nanoparticles are a consequence of their localized surface plasmon resonance (LSPR), which strongly depends on their size and shape [36]. This has made them ideal probes for diagnostic tests based on detecting color changes [37, 38]. Quantum dots are fluorescent nanoparticles whose emission wavelength is intimately related to their size. They are better suited for biosensing than traditional fluorophores because they do not bleach [39]. Furthermore, they have a broad absorption spectrum that makes it easy to excite them with a conventional UV lamp. This facilitates implementing them in in-field analyses and makes them ideal for multiplexed detections in which different quantum dots generate different fluorescent signals within the same experiment [20].

Finally, it is worth mentioning that micro- and nanostructured materials are making possible new approaches in biosensing that combine electrochemical and optical concepts. For example, self-propelled micro- and nanoparticles that use an electrochemical reaction as fuel have been proposed for detecting inflammation and pathogen biomarkers "on the fly" $[17,23,40,41]$. In this approach, the micro- and nanomotors swim in the sample and interact with the target analyte. Biorecognition alters the particle motion, which can be detected with optical methods. This approach is beneficial in that it circumvents the need to add additional instrumentation for sample convection (the biosensors are 
self-propelled) and requires very small sample volumes, which is ideal for analyzing samples from neonates.

\section{Biomarkers for sepsis management}

\section{Lactate}

Lactate is a useful biomarker for monitoring tissue oxygenation. Healthy individuals have basal blood lactate levels in the range between 0.5 and $1.5 \mathrm{mM}$ [42]. This value increases in the case of an inadequate tissue perfusion, when anaerobic metabolism is activated. An anomalous lactate elimination rate, which is normally $325 \mathrm{mM} \mathrm{h}^{-1}$, has been also suggested as a cause for hyperlactatemia [43]. Sepsis affects the cardiovascular system and vascular self-regulation, and often leads to tissue hypoperfusion, which may cause organ dysfunction [15]. This is usually accompanied by an increase in blood lactate. Thus, lactate is not a sepsis biomarker per se, since tissue hypoperfusion can be originated by other conditions. However, it is well-accepted that patients with persistent hyperlactatemia have poorer outcomes, and therefore, lactate is considered an excellent prognosis biomarker [44]. Fluid therapy, followed by vasopressors if no adequate response is obtained, is often used in order to decrease lactate levels and avoid poor outcomes.

In many hospitals, lactate is measured with tabletop gasometers. These devices only require injecting a blood sample in order to determine the concentration of lactate, as well as other relevant metabolites, within seconds. Point-of-care tests for lactate detection are also commercially available. Table $\mathrm{S} 1$ summarizes the main models currently available in the market. Table 1 comprises examples from the academic literature published the last 5 years.

\section{Procalcitonin}

Procalcitonin (PCT) is the precursor of the hormone calcitonin. It is released by parenchymal cells mainly in response to the presence of bacterial toxins, although it can also be found elevated to a lower extent in infections secondary to fungi or viruses [5]. It is found at very low basal levels (below $0.05 \mathrm{ng} \mathrm{mL}^{-1}$, which is considered "undetectable" from a clinical perspective), but its concentration in the bloodstream steadily increases during bacterial infections. Values above $1-2 \mathrm{ng} \mathrm{mL}^{-1}$ are usually considered a warning sign for sepsis [45]. Although alterations in PCT levels are indeed quite specific for bacterial infections, high levels of this biomarker can also be found in other non-infectious conditions such as pancreatitis, cancer, or trauma [5]. Nevertheless, PCT measurements are routinely used in many hospitals in order to aid in the diagnosis of sepsis. These are usually performed in central laboratories with automated
ELISA procedures such as Elecsys BRAHMS. It has also been suggested that the concentration of PCT in blood could be related to the pathogen causing sepsis [46]. PCT levels take about $4 \mathrm{~h}$ to elevate, and during this time, PCT measurements may lead to wrong conclusions [7]. However, PCT levels stay high for a long time, and therefore, it is a good biomarker for identifying sepsis independently of time in intermediate and late stages.

De-escalating antimicrobial therapies is essential for promoting antibiotic stewardship, and kinetic measurements of PCT are recommended for guiding this process. Current guidelines recommend de-escalating the antibiotic treatment when PCT decreases by $\geq 80 \%$ from peak value or below $0.5 \mathrm{ng} \mathrm{mL}^{-1}$ [47].

Table 2 shows the main features of biosensors for PCT detection proposed in the recent literature.

\section{Cytokines}

Cytokines are small proteins related to cell signaling in inflammatory processes such as sepsis. Pro-inflammatory cytokines such as IL-6 play an important role during the systemic inflammatory response syndrome and have been used to aid in the early diagnosis of sepsis [48]. IL-6 activates a downstream JAK kinase by interacting with soluble and membrane bound receptors as well as with the gp130 receptor. In healthy individual, the basal IL-6 concentration is below $10 \mathrm{pg} \mathrm{mL}^{-1}[49,50]$, although it is known that this concentration can be altered by chronic inflammation and aging. IL-6 is a useful biomarker to confirm suspected cases of sepsis and is used to monitoring the treatment as well [49, 51]. IL-6 levels higher than $20 \mathrm{pg} \mathrm{mL}^{-1}$ in neonates have been linked to sepsis [52]. In adults, IL-6 levels higher than $500 \mathrm{pg} \mathrm{mL}^{-1}$ lead to death in $11 \%$ of the cases, making it also a good prognosis biomarker [51].

The concentration of IL- 6 in serum peaks during the first hours of sepsis [7]. Then, it progressively decreases as PCT levels increase. Therefore, the combined monitoring of PCT and IL-6 could help identify sepsis cases irrespectively of disease stage.

Main approaches for detection IL-6 with biosensors can be found in Table 3

\section{C-reactive protein}

C-reactive protein (CRP) is an acute-phase reactant protein identified for the first time in 1930 [53]. CRP allows macrophages to eliminate bacteria by binding their phospholipid constituents [54]. Its synthesis is stimulated by cytokines such as IL- 6 or TNF- $\alpha$, a process that mainly takes place in the liver [55]. Even though evidence is lacking for its use as a specific sepsis biomarker [55, 56], it has good prognosis value as high CRP levels can be linked to the severity of 
Table 1 Examples of lactate micro- and nanosensors from the academic literature published the last 5 years

\begin{tabular}{|c|c|c|c|c|c|c|c|}
\hline Technique & Enzyme & Electrode & LOD & Dynamic range & Real sample & Assay time & Ref \\
\hline \multirow[t]{23}{*}{ Amperometry } & \multirow[t]{11}{*}{ LOX } & Prussian blue-modified carbon electrode & - & $0.2-5 \mathrm{mM}$ & serum & - & [104] \\
\hline & & $\begin{array}{l}\text { Linear poly(ethylenimine)-dimethylferro- } \\
\text { cene-modified glassy carbon electrode }\end{array}$ & $3 \mu \mathrm{M}$ & $0-5 \mathrm{mM}$ & - & - & [105] \\
\hline & & $\begin{array}{l}\text { Layer by layer poly(ethylenimine)- } \mathrm{CeO}_{2^{-}} \\
\text {modified Pt electrode }\end{array}$ & $0.3 \mu \mathrm{M}$ & $0.02-1 \mathrm{mM}$ & Serum & $10 \mathrm{~s}$ & [106] \\
\hline & & $\begin{array}{l}\text { Carboxylated multiwalled carbon nano- } \\
\text { tubes (cMWCNT)/copper nanoparticles } \\
\text { (CuNPs)/polyaniline (PANI) hybrid } \\
\text { film electrodeposited on the surface of a } \\
\text { pencil graphite electrode (PGE) }\end{array}$ & $0.25 \mu \mathrm{M}$ & $1 \mathrm{pM}-2.5 \mu \mathrm{M}$ & Serum & $5 \mathrm{~s}$ & [15] \\
\hline & & Prussian blue NP-modified electrode & $1 \mu \mathrm{M}$ & $1-100 \mu \mathrm{M}$ & Serum & - & {$[18]$} \\
\hline & & $\begin{array}{l}\text { Carbon-paste electrode modified with } \\
\text { Benzo }[c] \text { cinnoline and multiwalled } \\
\text { carbon nanotubes }\end{array}$ & $0.07 \mu \mathrm{M}$ & $0.2-100 \mu \mathrm{M}$ & Serum & $50 \mathrm{~s}$ & [31] \\
\hline & & $\begin{array}{l}\text { Screen-printed carbon electrodes with } \\
\text { platinum nanoparticle-decorated carbon } \\
\text { nanofibers }\end{array}$ & $11 \mu \mathrm{M}$ & $25 \mu \mathrm{M}-1.5 \mathrm{mM}$ & Blood & $60 \mathrm{~s}$ & [16] \\
\hline & & $\begin{array}{l}\mathrm{TiO}_{2} \text { sol/graphene modified 3D porous } \\
\mathrm{Ni} \text { foam }\end{array}$ & $19 \mu \mathrm{M}$ & $50 \mu \mathrm{M}-10 \mathrm{mM}$ & Serum & $180 \mathrm{~s}$ & [107] \\
\hline & & $\begin{array}{l}\text { Reduced graphene oxide, carbon nano- } \\
\text { tubes, and AuNP nanocomposite }\end{array}$ & $2.3 \mu \mathrm{M}$ & $0.05-100 \mathrm{mM}$ & Blood & $80 \mathrm{~s}$ & [27] \\
\hline & & Carbon nanodots & $0.9 \mu \mathrm{M}$ & $3-500 \mu \mathrm{M}$ & Serum & $38 \mathrm{~s}$ & [19] \\
\hline & & Platinum disk electrodes & $5 \mu \mathrm{M}$ & $5 \mu \mathrm{M}-1 \mathrm{mM}$ & Serum & $30 \mathrm{~s}$ & [108] \\
\hline & \multirow[t]{9}{*}{ LDH } & $\begin{array}{l}\text { Poly (3,4-dioxoethylthiophene) (PEDOT) } \\
\text { on } \mathrm{TiO}_{2} \text { nanowire }\end{array}$ & $0.08 \mu \mathrm{M}$ & $0.5-300 \mu \mathrm{M}$ & Serum & - & [109] \\
\hline & & $\mathrm{CeO}_{2}$-glassy carbon electrode & $50 \mu \mathrm{M}$ & $0.2-2 \mathrm{mM}$ & Blood & $4 \mathrm{~s}$ & [110] \\
\hline & & $\begin{array}{l}\text { Nitrophenyl modified reduced oxide } \\
\text { graphene electrode }\end{array}$ & $2.5 \mu \mathrm{M}$ & $0-90 \mu \mathrm{M}$ & Serum & $23 \mathrm{~s}$ & [26] \\
\hline & & $\begin{array}{l}\text { Graphene oxide nanoparticle-modified } \\
\text { pencil graphite electrode }\end{array}$ & $0.1 \mu \mathrm{M}$ & $5-50 \mathrm{mM}$ & Serum & $5 \mathrm{~s}$ & [111] \\
\hline & & $\begin{array}{l}\text { Gold NPs anchored on reduced graphene } \\
\text { oxide }\end{array}$ & $0.13 \mu \mathrm{M}$ & $10 \mu \mathrm{M}-5 \mathrm{mM}$ & Artificial serum & $6 s$ & [28] \\
\hline & & LDH NP-modified Au electrode & $0.01 \mu \mathrm{M}$ & $0.01 \mu \mathrm{M}-55 \mathrm{mM}$ & Serum & $2.5 \mathrm{~s}$ & [112] \\
\hline & & $\begin{array}{l}\text { Polyaniline Ti nanotubes-ethylvinylimi- } \\
\text { dazolium chloride-chloroauric acid }\end{array}$ & $0.16 \mu \mathrm{M}$ & $0.55 \mu \mathrm{M}-3.33 \mathrm{mM}$ & Serum & $8 \mathrm{~s}$ & [113] \\
\hline & & AuNP-modified microwire electrode & $411 \mu \mathrm{M}$ & $0.5-7 \mathrm{mM}$ & Serum & - & [114] \\
\hline & & $\begin{array}{l}\text { Poly(3,4-Dioxoethylthiophene) (PEDOT) } \\
\text { doped with poly(acrylamide-co- } \\
\text { acrylate) as polycarboxylate (poly- } \\
\text { COO-) }\end{array}$ & $0.25 \mathrm{mM}$ & $0.05-2 \mathrm{mM}$ & Serum & - & [115] \\
\hline & \multirow[t]{3}{*}{ None } & NiO@Au nanocomposite & $11.6 \mu \mathrm{M}$ & $\begin{array}{l}0.1-1.2 \mathrm{mM} \\
10-500 \mathrm{M}\end{array}$ & Serum & - & [116] \\
\hline & & Inkjet-printed AuNPs/NiO NP electrode & $380 \mathrm{mM}$ & $0.6-2.2 \mathrm{mM}$ & Plasma & $60 \mathrm{~s}$ & [117] \\
\hline & & $\begin{array}{l}\text { Pt-microneedle electrode-AuNPs-polydo- } \\
\text { pamine nanospheres }\end{array}$ & $50 \mu \mathrm{M}$ & $0.38-12 \mathrm{mM}$ & Serum & - & [118] \\
\hline Chemiluminescence & LOX & Luminol chemiluminescence detection & $15 \mu \mathrm{M}$ & $0.02-5 \mathrm{mM}$ & Serum & - & [119] \\
\hline Fluorimetry & LOX & $\begin{array}{l}\text { Polystrirene particles doped with Pt- } \\
\text { tetra(pentafluorophenyl) porphyrin }+ \text { sil- } \\
\text { ica particles with coumarin } 6\end{array}$ & $0.06 \mathrm{mM}$ & $0.1-0.8 \mathrm{mM}$ & Artificial serum & $<1 \min$ & [120] \\
\hline Field effect transistor & $\mathrm{LDH}$ & Graphene-based field effect transistor & - & $0-7.5 \mathrm{mM}$ & Serum & - & [121] \\
\hline Coulometry & LOX & $\begin{array}{l}\text { Commercial screen-printed electrode } \\
\text { (DS550, DropSens) }\end{array}$ & $0.25 \mathrm{mM}$ & $0-10 \mathrm{mM}$ & Serum & - & [122] \\
\hline
\end{tabular}


Table 2 Main micro- and nanosensors for PCT detection proposed in the recent literature

\begin{tabular}{|c|c|c|c|c|c|c|c|c|c|}
\hline \multirow[t]{2}{*}{ Technique } & \multirow[t]{2}{*}{ Detection } & \multirow[t]{2}{*}{ Support } & \multicolumn{3}{|l|}{ Instrumental } & \multicolumn{2}{|c|}{ Real matrix } & \multirow[t]{2}{*}{ Analysis time } & \multirow[t]{2}{*}{ Ref } \\
\hline & & & LOD & Matrix & Dynamic range & Matrix & LOD & & \\
\hline \multirow[t]{24}{*}{$\begin{array}{l}\text { Immu- } \\
\text { nosen- } \\
\text { sor }\end{array}$} & \multirow[t]{9}{*}{$\begin{array}{l}\text { Electro- } \\
\text { chemi- } \\
\text { cal }\end{array}$} & $\begin{array}{l}\text { Nylon membrane integrated } \\
\text { onto a microelectrode }\end{array}$ & $0.1 \mathrm{ng} \mathrm{mL}^{-1}$ & $\begin{array}{l}\text { PBS- } \\
\text { pooled } \\
\text { serum }\end{array}$ & $0.1 \mathrm{ng} \mathrm{mL}^{-1}-10 \mu \mathrm{g} \mathrm{mL}^{-1}$ & Blood & -- & $15 \mathrm{~min}$ & [123] \\
\hline & & $\begin{array}{l}\text { ZnNP-functionalized car- } \\
\text { bon-silica nanocomposite } \\
\text { graphene oxide }\end{array}$ & $13 \mathrm{fg} \mathrm{mL}^{-1}$ & -- & $50 \mathrm{pg} \mathrm{mL}^{-1}-80 \mathrm{ng} \mathrm{mL}^{-1}$ & Serum & $0.01 \mathrm{ng} \mathrm{mL}^{-1}$ & $>40 \min$ & {$[29]$} \\
\hline & & $\begin{array}{l}\text { Quantum dots (QD) and } \\
\text { indium-tin-oxide (ITO)- } \\
\text { coated glass substrate }\end{array}$ & $0.21 \mathrm{ng} \mathrm{mL}^{-1}$ & PBS & $1 \mathrm{ng} \mathrm{mL}^{-1}-10 \mu \mathrm{g} \mathrm{mL}^{-1}$ & - & -- & $>30 \mathrm{~min}$ & {$[20]$} \\
\hline & & $\begin{array}{l}\text { Magnetic beads and carbon } \\
\text { electrodes }\end{array}$ & $90 \mathrm{pg} \mathrm{mL}^{-1}$ & PBS & $0.25-100 \mathrm{ng} \mathrm{mL}^{-1}$ & Plasma & $0.6 \mathrm{ng} \mathrm{mL}^{-1}$ & $<20 \min$ & {$[21]$} \\
\hline & & $\begin{array}{l}\text { oO3/Au@ } \mathrm{rGO} \text { nanocom- } \\
\text { posites }\end{array}$ & $2 \mathrm{fg} \mathrm{mL^{-1 }}$ & PBS & $0.01 \mathrm{pg} \mathrm{mL}^{-1}-10 \mathrm{ng} \mathrm{mL}^{-1}$ & NO & NO & $>120 \mathrm{~min}$ & {$[124]$} \\
\hline & & $\begin{array}{l}\text { Glass carbon elec- } \\
\quad \text { trode }+\mathrm{CuCo}_{2} \mathrm{~S}_{4}-\mathrm{Au}-\mathrm{Ab}_{2}\end{array}$ & $82.6 \mathrm{fg} \mathrm{mL}^{-1}$ & PBS & $0.1 \mathrm{pg} \mathrm{mL}^{-1}-25 \mathrm{ng} \mathrm{mL}^{-1}$ & Serum & $<20 \mathrm{pg} \mathrm{mL}^{-1}$ & - & [125] \\
\hline & & $\begin{array}{l}\text { Magnetic beads + carbon } \\
\text { and gold electrodes }\end{array}$ & $\begin{array}{l}0.1(\mathrm{C}) \\
0.04(\mathrm{Au}) \mathrm{ng} \\
\mathrm{mL}^{-1}\end{array}$ & PBST & $\begin{array}{l}0.5-1000(\mathrm{C}) \\
0.1-20(\mathrm{Au}) \mathrm{ng} \mathrm{mL}^{-1}\end{array}$ & Serum & $1 \mathrm{ng} \mathrm{mL}^{-1}$ & $<20 \min$ & {$[22]$} \\
\hline & & $\begin{array}{l}\text { Magnetic beads + gold } \\
\text { electrodes }\end{array}$ & $20 \mathrm{pg} \mathrm{mL}^{-1}$ & PBST & $0.05-100 \mathrm{ng} \mathrm{mL}^{-1}$ & $\begin{array}{l}\text { Serum } \\
\text { plasma }\end{array}$ & -- & $<15 \min$ & {$[23]$} \\
\hline & & $\begin{array}{l}\text { Bismuth vanadate }+\mathrm{GaON} / \\
\text { CdS electrode }\end{array}$ & $0.03 \mathrm{pg} \mathrm{mL}^{-1}$ & PBS & $0.1 \mathrm{pg} \mathrm{mL}^{-1}-50 \mathrm{ng} \mathrm{mL}^{-1}$ & Serum & $0.05 \mathrm{ng} \mathrm{mL}^{-1}$ & $>60 \min$ & [126] \\
\hline & \multirow[t]{4}{*}{$\begin{array}{l}\text { Chemilu- } \\
\text { mines- } \\
\text { cence }\end{array}$} & $\begin{array}{l}\text { Polydimethylsiloxane } \\
\text { (PDMS) }\end{array}$ & $250 \mathrm{pg} \mathrm{mL}^{-1}$ & $\begin{array}{l}\text { PBS }(30 \% \\
\text { fetal calf } \\
\text { serum })\end{array}$ & $250 \mathrm{pg} \mathrm{mL}^{-1}-128 \mu \mathrm{g} \mathrm{mL}^{-1}$ & Serum & -- & $90 \mathrm{~min}$ & [127] \\
\hline & & Silica capillaries & $10 \mathrm{fg} \mathrm{mL}^{-1}$ & -- & $0.1 \mathrm{pg} \mathrm{mL}^{-1}-100 \mathrm{ng} \mathrm{mL}^{-1}$ & Serum & $20 \mathrm{pg} \mathrm{mL}^{-1}$ & $<3 \mathrm{~h}$ & [128] \\
\hline & & Bare fused silica & $0.5 \mathrm{pg} \mathrm{mL}^{-1}$ & - & $2.5 \mathrm{pg} \mathrm{mL}^{-1}-80 \mathrm{ng} \mathrm{mL}^{-1}$ & Serum & $23 \mathrm{pg} \mathrm{mL}^{--1}$ & $2.5 \mathrm{~h}$ & {$[129]$} \\
\hline & & Optical fiber & $11 \mathrm{pg} \mathrm{mL}^{-1}$ & PBS & $0.05-200 \mathrm{ng} \mathrm{mL}^{-1}$ & Serum & -- & $>75 \mathrm{~min}$ & [130] \\
\hline & \multirow{3}{*}{$\begin{array}{l}\text { Electro- } \\
\text { chemi- } \\
\text { lumines- } \\
\text { cence }\end{array}$} & $\begin{array}{l}\text { Graphene oxide + PANI } \\
\text { nanorod arrays + gold } \\
\text { nanoparticles }\end{array}$ & $54 \mathrm{fg} \mathrm{mL}^{-1}$ & PBS & $100 \mathrm{fg} \mathrm{mL}^{-1}-50 \mathrm{ng} \mathrm{mL}^{-1}$ & Serum & -- & $>40 \mathrm{~min}$ & [131] \\
\hline & & $\begin{array}{l}\text { Diethanolamine and ruthe- } \\
\text { nium co-doped in silica } \\
\text { nanoparticles }\end{array}$ & $0.85 \mathrm{pg} \mathrm{mL}^{-1}$ & PBS & $5 \mathrm{pg} \mathrm{mL}^{-1}-100 \mathrm{ng} \mathrm{mL}^{-1}$ & $\begin{array}{l}\text { Human } \\
\text { serum }\end{array}$ & $1 \mathrm{pg} \mathrm{mL}^{-1}$ & - & [132] \\
\hline & & $\begin{array}{l}\text { CoOOH@Au } \\
\text { NPs+g-C3N4@NH2- } \\
\text { MIL-101 }\end{array}$ & $3.4 \mathrm{fg} \mathrm{mL}^{-1}$ & PBS & $0.014 \mathrm{pg} \mathrm{mL}-40 \mathrm{ng} \mathrm{mL}^{-1}$ & $\begin{array}{l}\text { Human } \\
\text { serum }\end{array}$ & -- & $>120 \mathrm{~min}$ & [133] \\
\hline & \multirow{2}{*}{$\begin{array}{l}\text { Photoelec- } \\
\text { trochem- } \\
\text { ical }\end{array}$} & Zinc titanium composite & $30 \mathrm{fg} \mathrm{mL}^{-1}$ & Buffer & $0.1 \mathrm{pg} \mathrm{mL}^{-1}-100 \mathrm{ng} \mathrm{mL}^{-1}$ & Blood & $10 \mathrm{pg} \mathrm{mL}^{-1}$ & - & [134] \\
\hline & & $\begin{array}{l}\text { Acetylcholinesterase } \\
\text { connected to SiO2nano- } \\
\text { spheres }\end{array}$ & $0.17 \mathrm{pg} \mathrm{mL}^{-1}$ & PBS & $0.0005-100 \mathrm{ng} \mathrm{mL}^{-1}$ & $\begin{array}{l}\text { Human } \\
\text { serum }\end{array}$ & $0.17 \mathrm{ng} \mathrm{mL}^{-1}$ & $135 \mathrm{~min}$ & [135] \\
\hline & $\begin{array}{c}\text { Fluores- } \\
\text { cence }\end{array}$ & $\begin{array}{l}\text { Polypyrrole microtubes } \\
\text { with a magnetic layer of } \\
\text { nickel }\end{array}$ & $70 \mathrm{pg} \mathrm{mL}^{-1}$ & PBS & $0.5-150 \mathrm{ng} \mathrm{mL}^{-1}$ & Plasma & $1.1 \mathrm{ng} \mathrm{mL}^{-1}$ & $>30 \mathrm{~min}$ & {$[40]$} \\
\hline & $\begin{array}{l}\text { Lumines- } \\
\text { cence }\end{array}$ & $\begin{array}{l}\text { Core-shell mesoporous } \\
\text { silica nanoparticles + pol- } \\
\text { yvinyl chloride }\end{array}$ & $0.5 \mathrm{ng} \mathrm{mL}^{-1}$ & PBS & $1-200 \mathrm{ng} \mathrm{mL}^{-1}$ & Plasma & - & $>10 \mathrm{mn}$ & [39] \\
\hline & $\begin{array}{l}\text { Biolumi- } \\
\text { nescence }\end{array}$ & $\begin{array}{l}\text { Magnetic nanoparticle } \\
\text { polystyrene nanospheres }\end{array}$ & $45 \mathrm{ng} \mathrm{mL}^{-1}$ & $\begin{array}{l}\text { PBS } \\
\text { solution } \\
(30 \% \\
\text { fetal calf } \\
\text { serum) }\end{array}$ & $1-10^{4} \mathrm{pg} \mathrm{mL}^{-1}$ & Serum & $0.25 \mathrm{ng} \mathrm{mL}^{-1}$ & $1 \mathrm{~h}$ & [99] \\
\hline & SERS & Nitrocellulose & $0.1 \mathrm{ng} \mathrm{mL}^{-1}$ & PBST & $0.5-100 \mathrm{ng} \mathrm{mL}^{-1}$ & -- & -- & $15 \mathrm{~min}$ & [136] \\
\hline & $\begin{array}{r}\text { Plasmonic } \\
\text { imaging } \\
\text { platform }\end{array}$ & Gold-coated glass slide & $2.8 \mathrm{pg} \mathrm{mL}^{-1}$ & Buffer & $4.2 \mathrm{pg} \mathrm{mL}^{-1}-12.5 \mathrm{ng} \mathrm{mL}^{-1}$ & - & -- & $\sim 25 \min$ & {$[98]$} \\
\hline & $\begin{array}{l}\text { Colorimet- } \\
\text { ric }\end{array}$ & $\begin{array}{l}\text { Magnetic beads and filter } \\
\text { paper }\end{array}$ & -- & Blood & $1-20 \mathrm{ng} \mathrm{mL}^{-1}$ & Blood & $0.4-1.4 \mathrm{ng} \mathrm{mL}^{-1}$ & $13 \mathrm{~min}$ & {$[91]$} \\
\hline
\end{tabular}




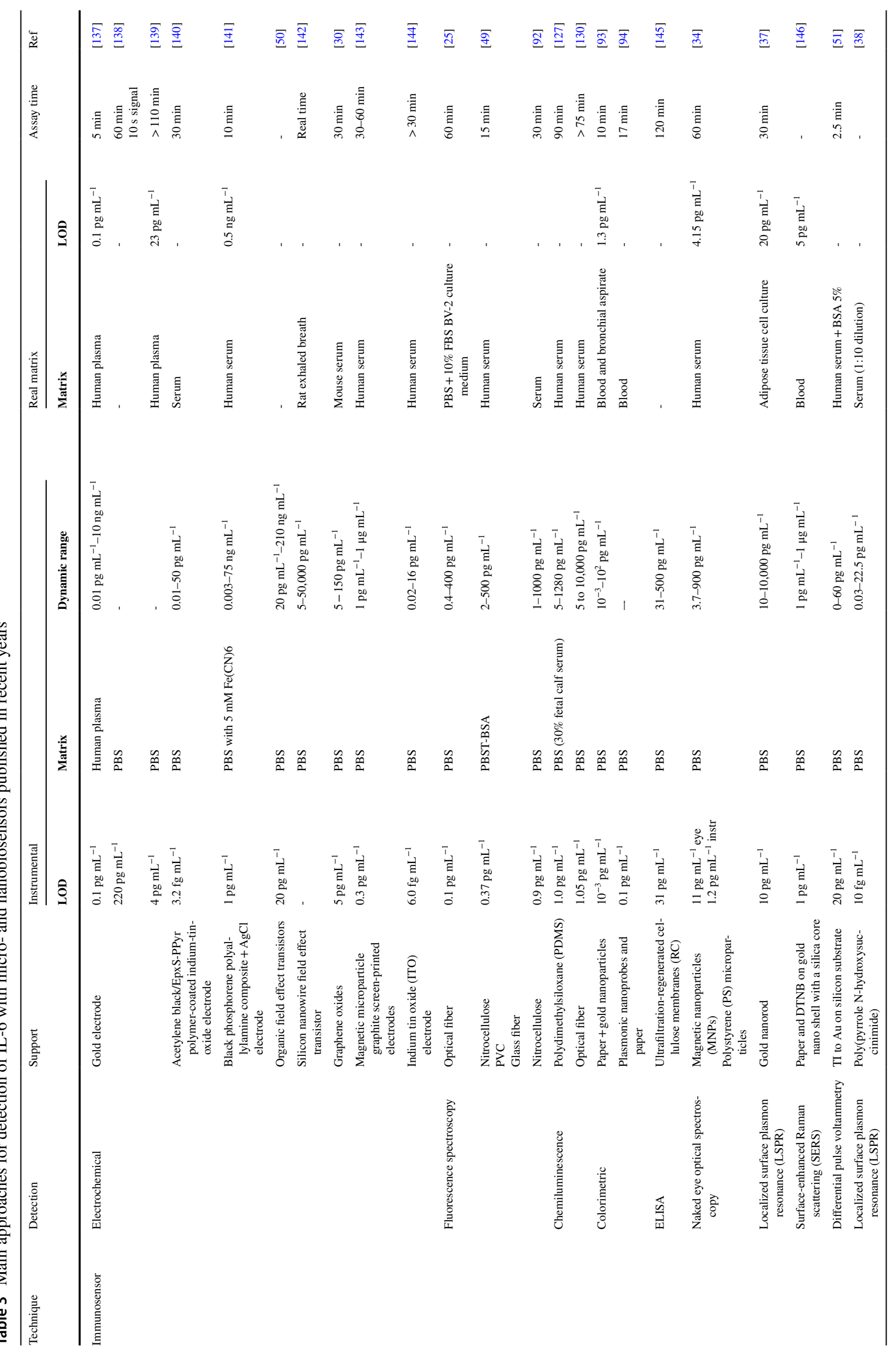




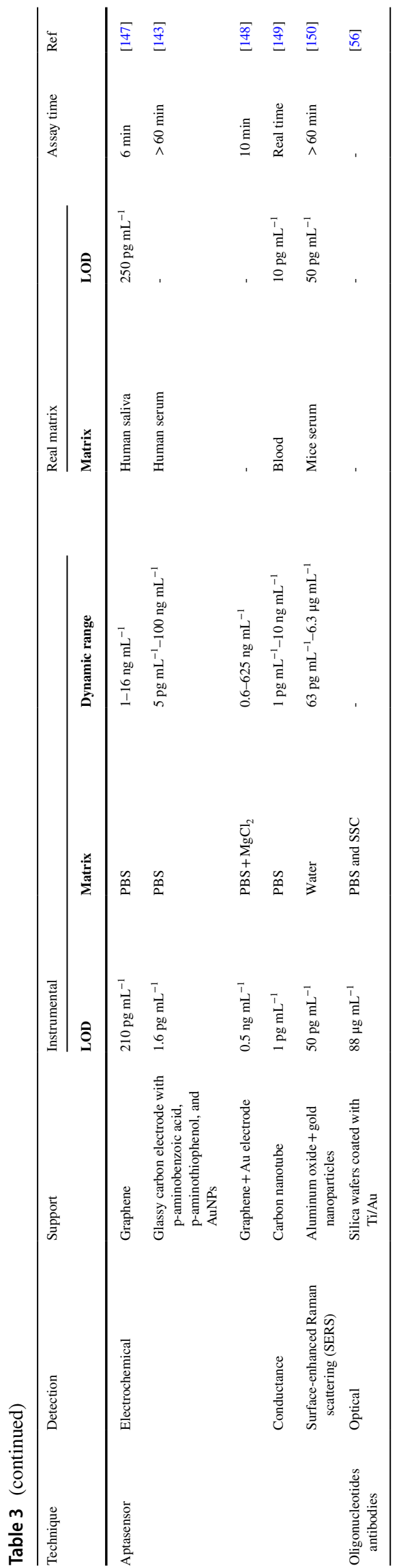

the infection [21]. Similarly, decreasing CRP values might indicate a favorable response to the antibiotic treatment [57]. However, CRP levels remain low during the first stages of the infection, and therefore, it has low sensitivity towards an early diagnosis of sepsis $[55,57]$. On the other hand, it has shown a strong selectivity to assess the severity of an infection after $24 \mathrm{~h}$.

Biosensors for CRP detection proposed in the last 5 years can be found in Table 4. Kumar et al. published an excellent compilation of technologies reported between 2006 and 2015 [8].

\section{Emerging biomarkers}

Adrenomedullin is a peptide with metabolic, immunomodulating, antimicrobial, and vasodilator activity [5]. It is synthesized as proadrenomedullin, which has short life in the blood stream. However, fragments of the prohormone such as mid-regional proadrenomedullin (MR-proADM) are not as rapidly metabolized and therefore are an excellent surrogate for measuring variations of proadrenomedullin originated by sepsis.

MR-proADM is mainly used as a prognosis biomarker, since high levels of this molecule for prolonged periods of time have been associated with poor outcomes [58]. Some authors even suggest that a single measurement of MRproADM can be as effective as the sequential organ failure assessment score (SOFA score) for evaluating organ dysfunction [59]. This is remarkable because the SOFA score requires multiple measurements of biochemical parameters and vital constants, and therefore, it is not suitable for the rapid assessment of patients.

Other biomarkers that could be useful for the diagnosis and prognosis of sepsis that are not used in the daily clinical practice as of yet are soluble CD14, also known as presepsin, a fragment of glycoprotein produced by monocytes or macrophages [60], sTREM-1 (soluble Triggering Receptor Expressed by Myeloid cells 1) [5], copeptin, a peptide derived from preprovasopressin [61], and suPAR (soluble urokinase-type plasminogen activator receptor) [62]. A meta-analysis comparing presepsin with PCT found no significant differences between the diagnostic sensitivity of these biomarkers for diagnosing sepsis, making it a valuable alternative to the classic biomarker [63]. Interestingly, presepsin has been found to be useful for identifying sepsis in the emergency department in several independent studies [64]. This makes this biomarker promising for the early identification of septic patients in this healthcare setting. Urine sTREM has been proposed as a potential biomarker for detecting urosepsis and acute kidney injury [65]. In serum, it has been shown to have excellent diagnostic value for ICU patients [66]. The same study revealed that suPAR can be used to predict bad outcomes and 7-day survival. 


\section{Non-protein biomarkers}

MicroRNAs (miRNAs) are non-coding RNAs containing 19-25 nucleotides that negatively regulate gene expression at the post-transcriptional level by binding to their target messenger RNAs. In recent years, the use of miRNAs as early biomarkers for clinical diagnosis of different types of disease has become a research hotspot. Differential expression of some miRNAs in septic patients compared to control patients suggests that miRNAs could be useful biomarkers in diagnostics or prognostic stratification. Table 5 shows the most consistently found miRNAs as potential biomarkers for sepsis. To the best of our knowledge, none of these biomarkers has been used as of yet in the routine clinical practice.

Although some miRNAs circulate freely, detection in circulation can be interfered by other components, making results less consistent. Alternatively, miRNAs are transported by small extracellular vesicles (EVs) such as exosomes, cell-derived membranous structures that work as intercellular communicators. They exert their function by transporting cargo, which includes nucleic acids, proteins, and lipids [67]. EVs protect miRNA from blood ribonucleases, giving exosomal miRNAs higher specificity and stability than circulating miRNAs thus becoming an ideal biomarker of circulating fluids. To detect exosomal miRNAs, EVs must be first purified from the biological samples and subsequently disrupted in order to quantify miRNAs. This is challenging because exosomes have nanoscale dimensions, which makes it difficult to purify them via conventional centrifugation. Moreover, miRNAs are found at very low concentrations. Therefore, their detection requires an ultrasensitive method, which often includes an approach to amplify their numbers such as PCR. However, PCR testing is expensive and requires several hours to be completed, which makes it unsuitable for the early diagnosis of sepsis. Isothermal amplification methods such as rolling circle amplification have been proposed for enabling the detection of miRNAs at low concentrations [68]. Nevertheless, the need for exosome purification, miRNA amplification, and ultrasensitive detection schemes makes it challenging to implement these biomarkers for the rapid diagnosis of sepsis in decentralized settings.

Advances in lab on chip technologies are making possible measuring cell-related biomarkers at the point of care. For example, it has been shown that red blood cells have reduced deformability in cases of sepsis, which could be used to diagnose the syndrome. This observation has prompted scientist to design microfluidic devices capable of measuring the shear modulus of these cells and determine their stiffness [69]. Recently, neutrophil motility has been proposed as a new biomarker for diagnosing sepsis. In this approach, neutrophil migration patterns were determined with a microfluidic device [70]. Samples from ICU patients were used to train a machine learning scoring system that could subsequently identify septic patients in a double-blind prospective study. The proposed method yielded a $97 \%$ sensitivity and $98 \%$ specificity when tested in a cohort of 42 patients. Expression of membrane markers in neutrophils is also useful for sepsis diagnosis, although its detection usually requires flow cytometry, a labor-intensive method that is not available at the point of care. This limitation was overcome with a microfluidic chip that detected the upregulated expression of CD64 on neutrophils using whole blood [71]. In this approach, red blood cells are lysed. The remaining cells are counted before and after circulating through a chamber modified with anti-CD64, which is the basis to determine the number of cells that have expressed this biomarker. The biochip shows an excellent diagnostic and prognostic accuracy when tested with patients at different times since hospital admission, which makes it promising for patient stratification. Finally, it has been proposed that plasmonic nanoparticles could be used to detect excessive degranulation in neutrophils isolated from septic patients [72]. In this approach, cationic proteins from neutrophil granules aggregate gold nanoparticles, which changes the color of the colloidal suspension. Neutrophils from septic patients have degranulated in vivo and therefore were not able to aggregate the nanoparticles in vitro. Combining this colorimetric signal generation mechanism with microfluidic of magnetic separation methods could make this approach useful in decentralized sepsis diagnostics.

\section{Detection of bacteriaemia}

Detecting the pathogen causing the infection in the bloodstream and its potential mechanisms of antimicrobial resistance is a powerful tool in sepsis management because it allows clinicians to personalize antibiotic treatments accordingly. However, it is important to note that patients may have sepsis without confirmed bacteriaemia and vice versa. Indeed, the current definition of sepsis (life-threatening organ dysfunction caused by a dysregulated host response to infection) does not include bacteriaemia.

Table S4 shows the main commercial approaches for detecting bacteria in blood. Bacteriological culture followed by a full antibiogram is the gold standard for detecting bacteria in blood. However, the whole process takes $24-48 \mathrm{~h}$ during which antibiotics must be provided empirically. Furthermore, this approach cannot detect viruses. Mass spectrometry can expedite the process, but it still requires a blood culture to increase the number of pathogens in the sample, which can be as low as $<10$ cells in $30-50 \mathrm{~mL}$ of blood [73]. PCR panels that detect a battery of pathogens and gens associated to antibiotic resistance in positive cultures are also commercially available. These approaches can simultaneously query the presence of different pathogens (including 


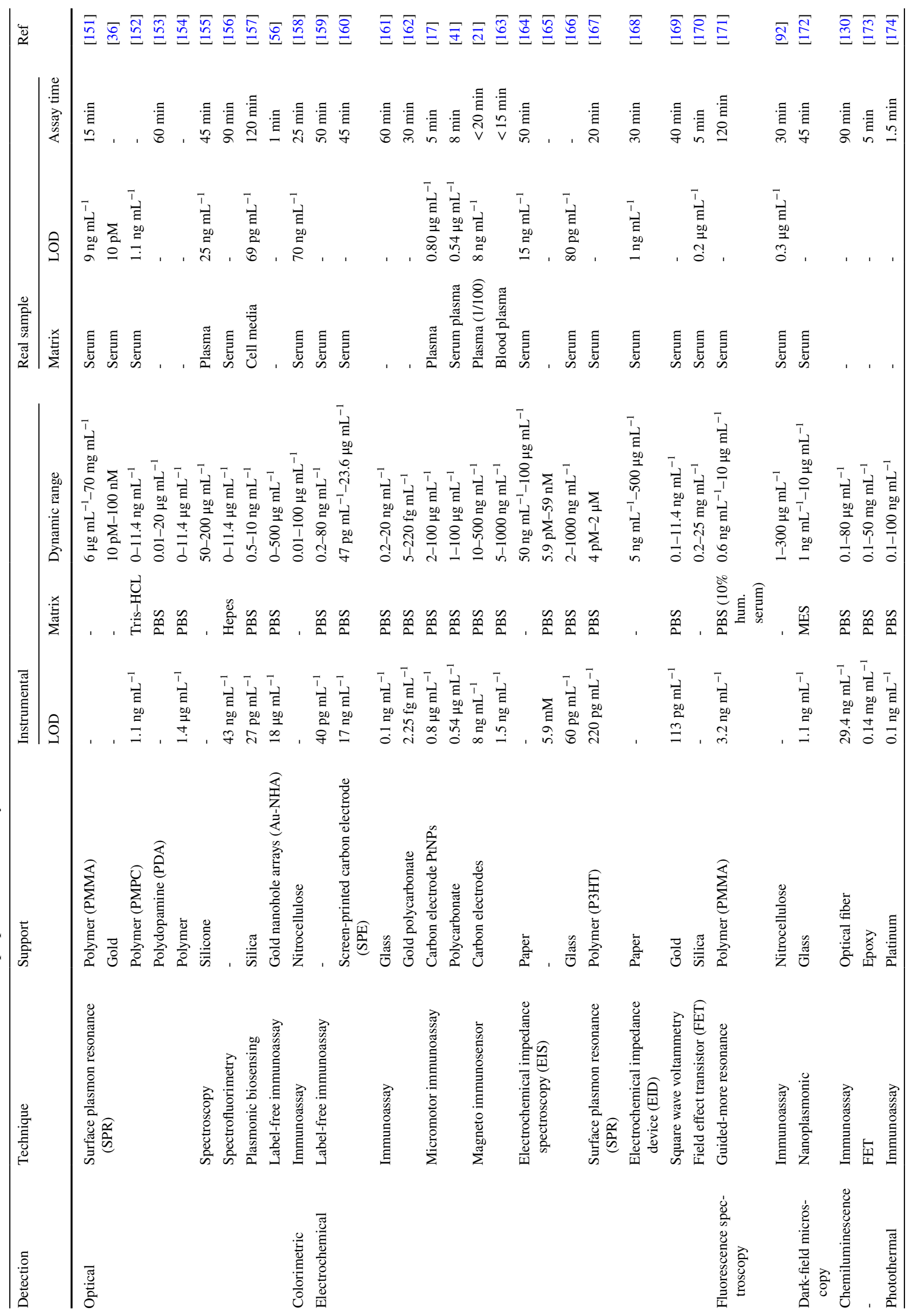


viruses). Noteworthily, a recent method from T2Biosystems has been proposed for detecting nucleic acids in $3-5 \mathrm{~h}$ without culture. This approach is based on promoting the clustering of magnetic nanoparticles through nucleic acid amplification, which affords a highly sensitive detection. Finally, the Accelerate Pheno system performs identification and antimicrobial susceptibility testing (AST) directly from positive blood cultures in ca. $7 \mathrm{~h}$. This approach is based on imaging changes in the morphology of cells triggered by the addition of antibiotics.

Recent new approaches for detecting pathogens in blood are summarized in Table 6. Many of these platforms offer extremely low limits of detection that could expedite the diagnosis of bacteriaemia when coupled to a shorter blood culture step [74-79]. Some are sensitive enough to be culture-independent [80-83]. Among this, an approach stands out for enabling the detection of a single pathogen per milliliter in less than $13 \mathrm{~min}$ [80]. It is based on using silver nanoparticles and an ultrasensitive technique, surface-enhanced Raman spectroscopy (SERS), to detect pathogens as they flow through a microfluidic system. The nanoparticles are modified with different reporter molecules that enable the simultaneous detection of several key pathogens in the sample. This technology could be a true game changer in sepsis management as it would allow clinicians to personalize antibiotic treatments way before blood cultures have been performed.

\section{Implementation points for decentralized measurements of sepsis biomarkers}

\section{Triage}

Around 50\% of sepsis patients enter the hospital through the emergency department, where they are initially evaluated by a nurse during triage [84]. Triage consists of a series of quick examinations that allow the nurse to establish the urgency required for the patient to be attended by a doctor. Patients are assigned a priority level that determines their waiting time. For example, the Manchester triage system has 5 levels, level 1 patients require immediate attention; level 2 patients should not wait more than 10-15 min; levels 3-4 are delayed by 1 or $2 \mathrm{~h}$, respectively; and level 5 are not considered emergency cases and may wait more than $4 \mathrm{~h}$. Therefore, the aim of nurse triage is not diagnosing a particular pathology but rather prioritizing patients that require urgent care. Nurse triage should not take more than 5-10 min to be completed.

Nurse triage has been recognized as one of the main bottlenecks in sepsis care, as patients that arrive to the emergency room with mild symptoms can rapidly worsen while sitting for hours in the waiting room if they are not 
prioritized correctly. High lactate levels are indicative of bad outcomes, and biosensors for rapid lactate detection in whole blood are already available (Table S1). Several clinical studies have validated that lactate measurements can improve triage [85]. Indeed, The Third International Consensus Definitions for Sepsis and Septic Shock (Sepsis-3) stated that septic shock, which has a poor prognosis, could be identified by a vasopressor requirement to maintain a mean arterial pressure of $65 \mathrm{mmHg}$ or greater and serum lactate level greater than $2 \mathrm{mmol} \mathrm{L}^{-1}\left(>18 \mathrm{mg} \mathrm{dL}^{-1}\right)$ in the absence of hypovolemia [86]. Thus, bedside methods for the rapid detection of lactate are required in order to monitor patients at risk of septic shock and prioritize them accordingly. However, lactate levels vary very rapidly, and they are not specific for sepsis. Therefore, lactate determinations should be complemented with measurements of IL-6, PCT, or MR-proADM measurements [87]. In the context of triage, these measurements should be rapid and easy to perform and interpret by a frontline healthcare worker with only a drop of capillary blood. Combining these measurements with advances in machine learning, which have shown to improve sepsis diagnosis even with scarce data sets [88, 89], could help prioritize patients that need urgent care [90].

Commercial lateral flow immunoassays for PCT and IL-6 require $20 \mathrm{~min}$ to be completed, and they are not recommended for analyzing whole blood (Tables S2 and S3). Biosensors that could reduce the assay time and detect biomarkers in unprocessed blood could make a great impact in the triaging of sepsis patients. For example, a recent prototype in the literature was able to detect PCT in whole blood within 13 min with a paper biosensor and a smartphone reader [91]. In this approach, magnetic microparticles captured PCT through a competitive immunoassay using catalase as a label. The magnetic particles were spotted on a paper substrate, which generated an intensely colored spot due to the inherent brown color of the iron oxide beads (Fig. 1A). Then, hydrogen peroxide was added, and catalase generated oxygen bubbles that dispersed the particles within the paper in a few seconds. The corresponding change in color was then quantified with a smartphone app. This detection scheme combines a fast turnaround time with a mobile reader, which is ideal for decentralized measurements such as the ones required in triage.

As commented above, IL-6 is one of the earliest biomarkers that is altered during sepsis, making it ideal for the early identification of at-risk patients during triage. Recently, a lateral flow immunoassay (LFIA) that measured IL-6 with a portable fluorescence strip reader (PorFloR ${ }^{\mathrm{TM}}$ ) was developed [92]. Staphylococcal protein A (SPA) conjugated with CdTe QDs, anti-IL-6, and anti-rabbit IgG are bound separately on SPA-QD complex to develop the biosensor mixture (Fig. 1B). The device includes a control and test spots. The test showed a low limit of detection of $0.9 \mathrm{pg} \mathrm{mL}^{-1}$ with a wide dynamic range between 1 and $1000 \mathrm{pg} \mathrm{mL}^{-1}$. The performance of the device, in terms of sensitivity, selectivity, and analysis time (30 min) shows potential as a PoC device for the analysis of IL-6 in patients with infection. However, sample treatment is needed and the device has still to be tested in patient samples.

Recently, an alternative has emerged that used a colorimetric detection scheme and smartphone readouts for detecting IL-6 in whole blood with a paper biosensor within $10 \mathrm{~min}$ [93]. In this approach, the sample is dried on a piece of filter paper, and then, nanoparticles are transferred from another paper biosensor. The nanoparticles are covered with anti-IL-6 antibodies that specifically recognized the target with an incubation step of only $5 \mathrm{~min}$. The biosensors showed an ultralow limit of detection of $10^{-3} \mathrm{pg} \mathrm{mL}^{-1}$ in ideal conditions that enabled a sample dilution step for eliminating interference from the blood matrix that circumvented the need to purify serum or plasma. Colorimetric signals were read with a smartphone app that uses an augmented reality guidance system to eliminate artifacts [94]. While the rapid turnaround time and smartphone-based detection scheme make this approach suitable for decentralized analyses, further work is needed to match the easy manipulation of the lateral flow immunoassay, especially with regard to washing steps.

A platform for the detection of IL-3 has also shown promising results towards an early diagnosis and prognosis of sepsis [95]. It is a hybrid magneto-electrochemical sensor which produces results in $1 \mathrm{~h}$ from native blood samples. First, IL-3 is captured from native blood using magnetic microparticles and is labeled with antibodies conjugated to HRP. Then, magnetic beds are mixed with TMB and the oxidized TMB is reduced by the electrode transducer. The electrical current generated can be related to IL-3 concentration in the sample, with a limit of detection below $10 \mathrm{pg} \mathrm{mL}^{-1}$. The fact that blood can be used without any sample treatment, and the low volume required (less than $100 \mu \mathrm{L}$ ) makes the device a good candidate for point-of-care implementation. Moreover, the device is small $\left(10 \times 10 \times 2.5 \mathrm{~cm}^{3}\right)$ and thus can be easily fitted in a nurse office.

As for lactate biosensors, dynamic range and measure time are two key points that need to be optimized to make the sensor useful for triage. A wide dynamic range is necessary to distinguish normal physiological concentrations from alarmingly high concentrations, which would allow to prioritize patients with a bad prognosis. A biosensor based on a platinum electrode modified with reduced graphene oxide, carbon nanotubes, and gold nanoparticles has been proposed as a good candidate to meet this challenge [27]. In this approach, lactate oxidase, which catalyzes the conversion of lactate to $\mathrm{H}_{2} \mathrm{O}_{2}$ and pyruvate, is immobilized in the electrode surface. The amperometric signal resulting from 
the oxidation of $\mathrm{H}_{2} \mathrm{O}_{2}$ can be related to the L-lactate concentration in the sample. The device showed a very wide dynamic range $(0.05-100 \mathrm{mM})$, and could detect lactate in blood samples, making it useful for patient prioritization at the point-of-care.

\section{Emergency room}

After nurse triage, the patient will be visited by a clinician in the emergency room, who will diagnose the patient. For external patients, the information available for the diagnosis is still very limited. Measurements of vital constants performed during nurse triage will be repeated and laboratory tests will be commissioned. These will include immunological determinations such as lymphocyte counts and organ dysfunction tests such as the quantification of bilirubin. In many hospitals, these tests will be complemented with laboratory-based measurements of CRP and PCT. It has been already shown that combining biomarker measurements with data from electronic medical records could improve the sensitivity and specificity towards sepsis diagnosis [96]. Rapid diagnostic tests performed at the bedside and machine learning algorithms could streamline this diagnostic paradigm in the near future.

Two analytical advances could make a great impact in the diagnosis of sepsis at this point. On the one hand, repeating the rapid measurements proposed during nurse triage could shed light into patient progression. As highlighted above, sepsis is strongly time-dependent. Determining variations in biomarkers with time could reveal patients that are quickly worsening before all the battery of laboratory tests is completed. On the other hand, biosensors for determining multiple sepsis biomarkers simultaneously would be a tremendous help for diagnosing sepsis, since little information is known at this point. An elegant example of such platform is a nanoplasmonic biosensor microarray for the multiplex detection of cytokines [97]. This device comprises 480 nanoplasmonic sensing spots in a microfluidic device that can be completely run within $40 \mathrm{~min}$. The array measures changes in the localized surface plasmon resonance of gold nanorods modified with antibodies upon target binding. The readout is performed with dark-field microscopy. Authors demonstrated the simultaneous detection of IL-2, IL-4, IL-6, IL-10, TNF- $\alpha$, and IFN- $\gamma$ with these devices. Adapting this technology for using compact readers such as mobile phones, which have been repurposed as point-ofneed dark-field microscopes, and incorporating a purification step for direct blood determination at the bedside could be a game changer in sepsis diagnosis at the point-of-care.

Electrochemical biosensors for the simultaneous detection of PCT and CRP have also been proposed in the literature (Fig. 2) [21]. In this approach, antibody-decorated magnetic microparticles captured the biomarkers, which were subsequently detected with a sandwich immunoassay using horseradish peroxidase as the label. The enzyme oxidized hydroquinone in the presence of hydrogen peroxide, which generated dose-dependent signals. The whole assay was performed within $20 \mathrm{~min}$, making it suitable for the rapid identification of sepsis. Detection was accomplished with a portable potentiostat/galvanostat using a small drop of sample $(30 \mu \mathrm{L})$, which makes it useful for diagnosing sepsis in neonates.

In the emergency room, patients that have been identified as septic will receive their first antibiotic treatment. Methods for expediting the identification of pathogens in blood could greatly help clinicians decide on the best treatment option. For example, it has been shown that a microfluidic system can detect pathogens in blood at the single cell level within 90 min using DNAzymes. The DNAZyme recognized and cleaved target molecules produced by Escherichia coli thanks to its biocalytic activity. This turned a fluorescent reporter on that enabling the detection of single bacterial cells [78]. Encapsulating each bacterium in a microscopic droplet was a key aspect to achieve ultra-high sensitivity, as it greatly increased the concentration of targets that are recognized and cleaved by the DNAzyme. Electrochemical methods have also been applied for the rapid detection of bacteria at ultralow concentration in plasma [81]. In this approach, redox-active probes consisting of a gold core surrounded by electropolymerized 4-aminothiophenol (4-ATP), or (B) 5-amino-2-mercapto-1,3,4-thiadiazole (AMT), and antibodies were used to target the bacteria. Pathogens were detected with electrodes implemented in a nano-sieving microfluidic system that removed probes not bound to the bacteria. Using this method, pathogens at concentrations as low as 10 cells $\mathrm{mL}^{-1}$ could be detected within $30 \mathrm{~min}$, which could be fast enough to fine-tune the first antibiotic regimen according to the type of pathogen generating the infection.

\section{Intensive care unit}

Patients in the ICU may acquire nosocomial infections by multi-resistant pathogens that can easily progress to sepsis if not timely treated. Immunosuppressed patients, as well as those previously treated with antibiotics, on mechanical ventilation, or wearing catheters, are particularly susceptible. Thus, tools for rapid diagnosis highlighted in the previous sections are also relevant for identifying sepsis cases in the ICU. Once diagnosed, it is crucial to closely monitor patient progression. Thus, the rapid detection of biomarkers along the chain of care should be complemented with a system for real-time data collation and sharing. An "Internet of Things" paradigm that enabled the direct communication between biosensors and electronic health records could make this idea a reality.

As highlighted above, serial measurements of PCT are recommended in order to de-escalate the antibiotic treatment. 
Table 5 Biosensors for the detection of miRNAs as potential biomarkers for sepsis

\begin{tabular}{|c|c|c|c|c|c|}
\hline Detection & miRNA strand & Dynamic range & LOD & Matrix & Ref \\
\hline \multirow[t]{5}{*}{ Colorimetric } & $\begin{array}{l}-21 \\
-155 \\
-210\end{array}$ & $\begin{array}{l}0-10 \mathrm{nM} \\
0-5 \mathrm{nM} \\
0-10 \mathrm{nM}\end{array}$ & $\begin{array}{l}73 \mathrm{pM} \\
61 \mathrm{pM} \\
85 \mathrm{pM}\end{array}$ & Spiked serum & [178] \\
\hline & 208 & $10 \mathrm{fM}-100 \mathrm{nM}$ & $10 \mathrm{fM}$ & Serum & [179] \\
\hline & - & $0.01-1 \mathrm{nM}$ & $250 \mathrm{pM}$ & Cell lysate & [180] \\
\hline & 148 & $0.1-1000 \mathrm{nM}$ & $1.9 \mathrm{nM}$ & Buffer & [181] \\
\hline & 10 & $5 \mathrm{pM}-10 \mathrm{nM}$ & $2.45 \mathrm{pM}$ & $\begin{array}{l}\text { Urine (mice) } \\
\text { Plasma (mice) }\end{array}$ & [182] \\
\hline $\begin{array}{l}\text { Colorimetric and } \\
\text { fluorescence }\end{array}$ & 21 & $50 \mathrm{pM}-1 \mathrm{nM}$ & $50 \mathrm{pM}$ & Cell lysate & [183] \\
\hline \multirow[t]{5}{*}{ Electrochemical } & 21 & $5 \mathrm{fM}-100 \mathrm{pM}$ & $2.7 \mathrm{fM}$ & Spiked serum & [184] \\
\hline & & $10 \mathrm{aM}-1 \mu \mathrm{M}$ & $38 \mathrm{aM}$ & Cell lysate & [185] \\
\hline & & $0.1 \mathrm{fM}-10 \mathrm{pM}$ & $0.03 \mathrm{fM}$ & Cancer cells & [186] \\
\hline & $\begin{array}{l}21 \\
126\end{array}$ & $20 \mathrm{fM}-50 \mathrm{pM}$ & $5.36 \mathrm{fM}$ & Cancer cells & [187] \\
\hline & $\begin{array}{l}21 \\
141\end{array}$ & $\begin{array}{l}0.5-1000 \mathrm{pM} \\
50-1000 \mathrm{pM}\end{array}$ & $\begin{array}{l}0.3 \mathrm{pM} \\
10 \mathrm{pM}\end{array}$ & Spiked serum & [188] \\
\hline
\end{tabular}

This requires an analytical platform capable of performing quantitative analysis over a wide dynamic in order to detect $80 \%$ variations over peak values, and with a low limit of detection for those cases where PCT drops below $0.5 \mathrm{ng} \mathrm{mL}^{-1}$. For example, a plasmonic platform was recently introduced for detecting PCT in serum in the concentration range between
4.2 and 12,500 $\mathrm{pg} \mathrm{mL}^{-1}$ in less than $25 \mathrm{~min}$ (Fig. 3A) [98]. In this approach, PCT is captured by a sandwich immunoassay on a gold-covered glass chip. The detection antibodies are labeled with biotin, which interacts with streptavidin-coated gold nanoparticles. The binding of PCT to the sensor is then monitored with a plasmonic platform that uses $\mathrm{p}$-polarized

Table 6 New approaches for detecting pathogens in blood

\begin{tabular}{|c|c|c|c|c|c|c|}
\hline Pathogen & Technique & Support & LOD & Dynamic range & $\begin{array}{l}\text { Analysis } \\
\text { time } \\
(\mathrm{min})\end{array}$ & Ref \\
\hline \multirow[t]{3}{*}{ E. coli } & $\begin{array}{l}\text { Immunosensor + optical } \\
\text { interferometry }\end{array}$ & Gold & $10^{2}$ cell $\mathrm{mL}^{-1}$ & $10^{2}-10^{5}$ cell $\mathrm{mL}^{-1}$ & 40 & {$[74]$} \\
\hline & Aptasensor + plasmonic & AuNPs & $40 \mathrm{CFU} \mathrm{mL} \mathrm{m}^{-1}$ & $10^{2}-10^{6} \mathrm{CFU} \mathrm{mL}^{-1}$ & 60 & {$[75]$} \\
\hline & DNAzyme + fluorescence & PDMS and oil & $1 \mathrm{CFU} \mathrm{mL} \mathrm{m}^{-1}$ & $1-10^{4} \mathrm{CFU} \mathrm{mL} \mathrm{m}^{-1}$ & 90 & {$[80]$} \\
\hline $\begin{array}{l}\text { E. coli } \\
\text { P. aeruginosa }\end{array}$ & $\begin{array}{l}\text { Bacteriophage assay }+ \text { biolu- } \\
\text { minescence }\end{array}$ & Polystyrene & $100 \mathrm{CFU} \mathrm{mL} \mathrm{m}^{-1}$ & $10^{2}-10^{6} \mathrm{CFU} \mathrm{mL}^{-1}$ & $>60$ & [76] \\
\hline S. aureus & $\begin{array}{l}\text { Antimicrobial pep- } \\
\text { tide + SERS }\end{array}$ & $\begin{array}{l}\text { Magnetic particles }+\mathrm{Au}- \\
\text { coated Ag-decorated } \\
\text { graphene oxide nanocom- } \\
\text { posites }\end{array}$ & $10 \mathrm{CFU} \mathrm{mL} \mathrm{m}^{-1}$ & $10-10^{6} \mathrm{CFU} \mathrm{mL}^{-1}$ & $>60$ & [81] \\
\hline $\begin{array}{l}\text { E. coli } \\
\text { P. aeruginosa } \\
\text { S. aureus } \\
\text { S. pyogenes }\end{array}$ & $\begin{array}{l}\text { Protein aggregation } \\
\text { assay + fluorescence }\end{array}$ & $\begin{array}{l}\mathrm{Au} \text { and } \mathrm{Cu} \text { nanoclusters on } \\
\text { paper }\end{array}$ & 26-63 CFU mL $\mathrm{mL}^{-1}$ & $10^{2}-10^{8} \mathrm{CFU} \mathrm{mL}{ }^{-1}$ & 1 & [77] \\
\hline $\begin{array}{l}\text { E. coli } \\
\text { P. aeruginosa } \\
\text { S. aureus } \\
\text { S. agalactiae }\end{array}$ & Immunosensor + SERS & AgNPs & $1 \mathrm{CFU} \mathrm{mL} \mathrm{m}^{-1}$ & $1-10^{2} \mathrm{CFU} \mathrm{mL} \mathrm{m}^{-1}$ & 13 & {$[82]$} \\
\hline $\begin{array}{l}\text { E. coli ATCC } 25,922 \\
\text { Staphylococcus capitis }\end{array}$ & $\begin{array}{l}\text { Metabolic activity + photo- } \\
\text { catalytic + colorimetric }\end{array}$ & Filter paper & $10^{3} \mathrm{CFU} \mathrm{mL}^{-1}$ & $10^{3}-10^{8} \mathrm{CFU} \mathrm{mL}^{-1}$ & $<300$ & {$[78]$} \\
\hline $\begin{array}{l}\text { P. aeruginosa } \\
\text { S. aureus }\end{array}$ & $\begin{array}{l}\text { Immunosensor + ampero- } \\
\text { metric }\end{array}$ & Redox-active AuNPs & $10 \mathrm{CFU} \mathrm{mL} \mathrm{m}^{-1}$ & $10-10^{5} \mathrm{CFU} \mathrm{mL}^{-1}$ & 30 & [83] \\
\hline B. cereus & DNA + bioluminescence & Magnetic nanoparticles & $10^{3} \mathrm{CFU} \mathrm{mL} \mathrm{m}^{-1}$ & $10^{3}-10^{6} \mathrm{CFU} \mathrm{mL}^{-1}$ & 30 & [79] \\
\hline
\end{tabular}


Fig. 1 Examples of biosensors for PCT detection. A Motionto-color biosensors based on a competitive immunoassay on magnetic microparticles. Magnetic particles that capture PCT are spotted on a piece of paper, which generates a colored spot due to the brown color of the iron oxide. After the addition of hydrogen peroxide, the particles are dispersed due to the oxygen bubbles generated by catalase and the change in color is quantified with a smartphone. Adapted with permission from reference [36] (Elsevier 2019). B LFIA for the detection of IL-6. The paper strip is read with a portable fluorimeter (PorFloR ${ }^{\mathrm{TM}}$ ). Adapted with permission from ref. [37] (Elsevier 2019)

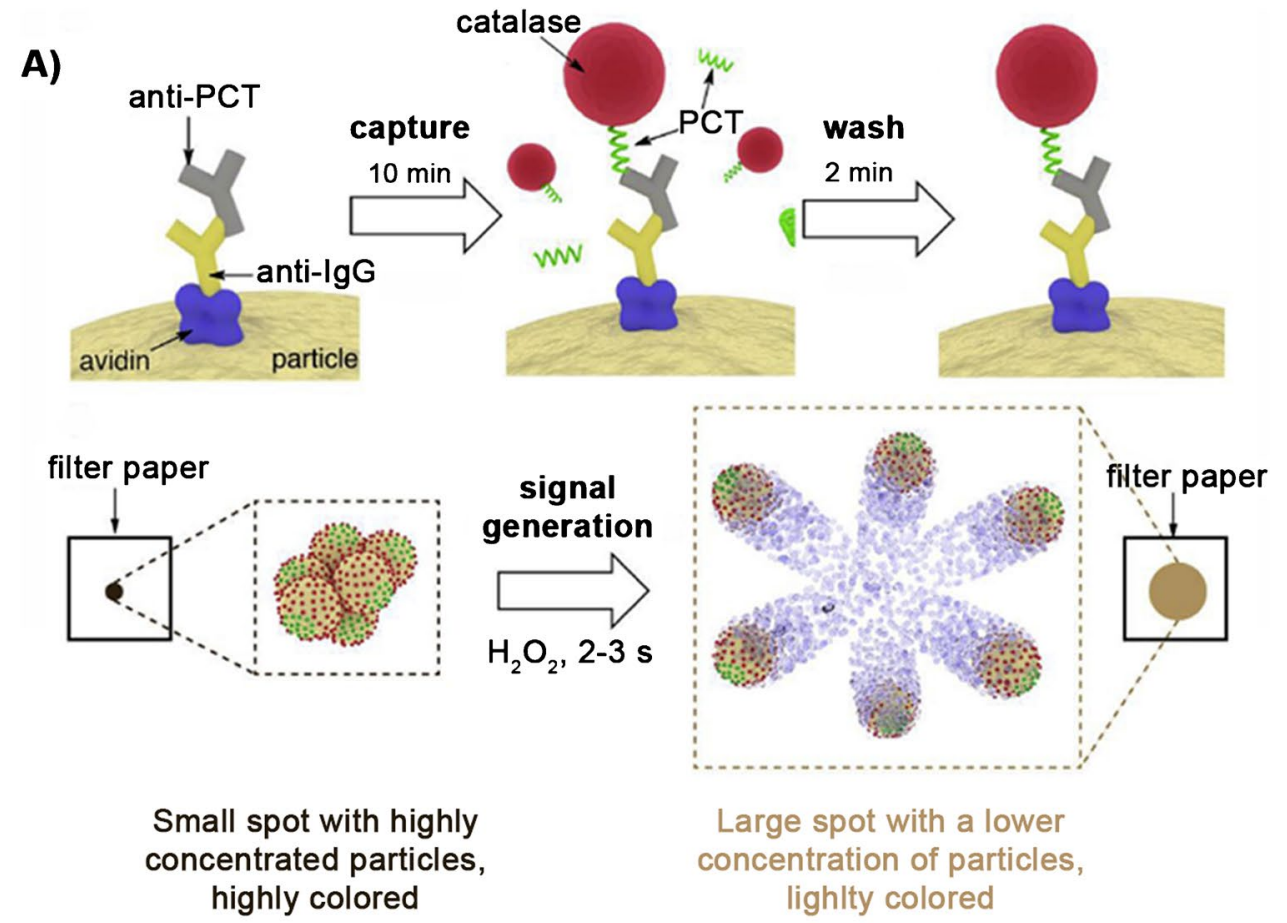

B)

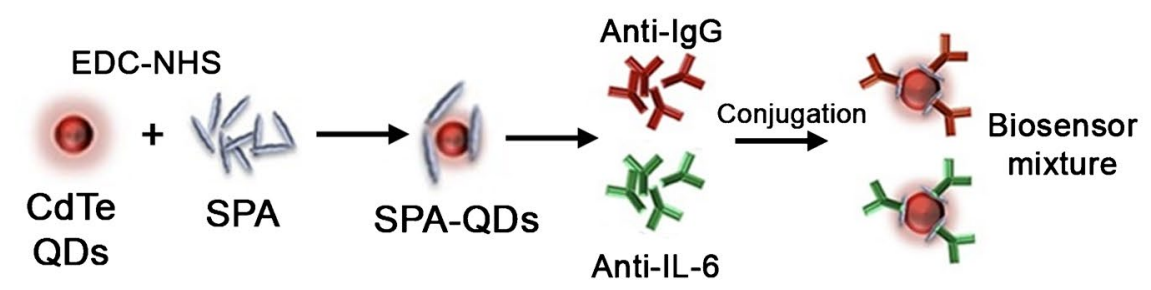

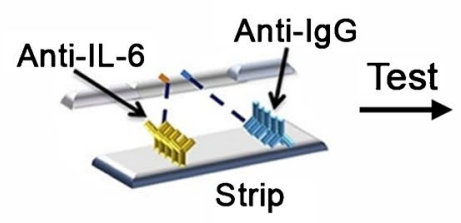
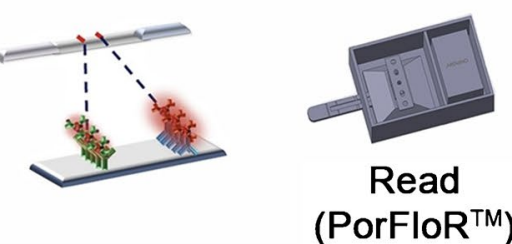

light from a super luminescent emitting diode to excite plasmons on the gold surface. The resulting scattered and reflected light can be used to image individual gold nanoparticles a temporal resolution of $\sim 37.5 \mathrm{~ms}$. This unique feature enables resolving multiple nanoparticle binding events in an area comprised within the diffraction limit, which is responsible for the reported wide dynamic range.

Another promising point-of-care tool to detect PCT was presented in 2017 [99]. The device utilizes a double enzyme reaction where the ATP-luciferin-luciferase bioluminescent signal is produced and measured by a portable detector (Fig. 3B). The total assay time is less than $1 \mathrm{~h}$ with a wide working range of 1 to $10^{4} \mathrm{pg} \mathrm{mL}^{-1}$ and a low LOD $\left(0.045 \mathrm{pg} \mathrm{mL}^{-1}\right)$. In this method, a sandwich immunoassay is performed employing magnetic nanoparticles modified with anti-PCT (monoclonal) and polystyrene nanospheres conjugated with both anti-PCT and the enzyme alkaline phosphatase (ALP). ALP, in the presence of the analyte, dephosphorylates ATP, thus inhibiting luciferase action and therefore reducing the production of the bioluminescent 
Fig. 2 Electrochemical biosensor for the simultaneous detection of PCT and CRP. Antibody-decorated magnetic particles capture PCT and CRP, and afterwards, the biomarkers are quantified by a sandwich immunoassay with HRP as the label. The total analysis time is $20 \mathrm{~min}$ and only $30 \mu \mathrm{L}$ of sample are needed. Reproduced with permission from ref. [43] (American Chemical Society 2019)
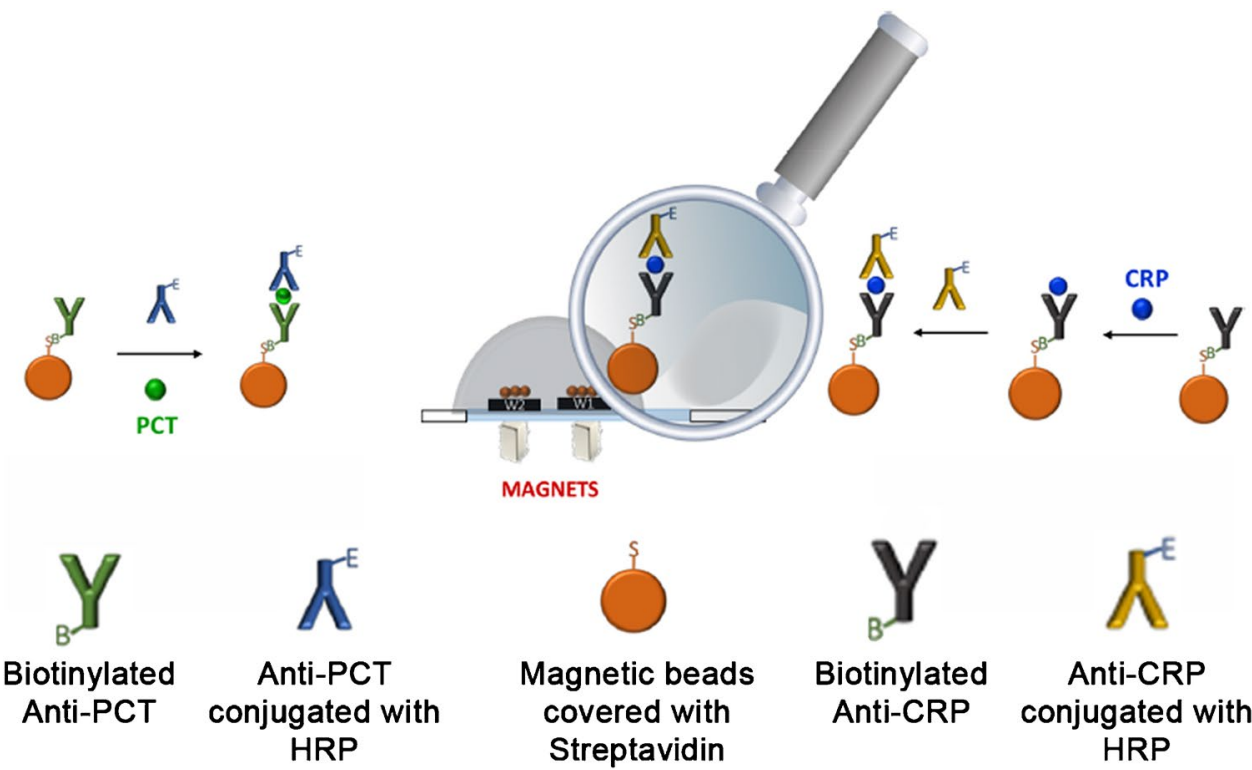

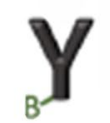

Biotinylated Anti-CRP

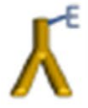

Anti-CRP conjugated with HRP signal. The device was applied to real clinical samples and showed good correlation with standard devices.

\section{Other hospital departments}

Oncology patients are often immunocompromised by the chemotherapy and other immunosuppressed drugs, and therefore, they are at higher risk of sepsis. Patients that have undergone invasive procedures (surgeries) also need to be closely monitored for nosocomial infections potentially leading to sepsis. An implantable biosensor for the real-time detection of cytokines has been recently proposed that could revolutionize sepsis care in these scenarios. It consists of a graphene oxide transducer modified with an aptamer that changes its conformation upon binding interferon $\gamma$ (IFN$\gamma$ ) (Fig. 4A) [100]. The binding releases ruthenium complexes encapsulated in the closed aptamer configuration, which in turn generates an electrochemical signal. The sensors had a low limit of detection of $1.3 \mathrm{pg} \mathrm{mL}^{-1}$, and it was able to detect changes in the inflammatory state of mice in vivo during $48 \mathrm{~h}$. Adapting this technology to monitor inflammation biomarkers in at-risk patients could be a game changer in sepsis care. It could also help better understand the syndrome, as it would provide information about time fluctuations in sepsis biomarkers. A label-free biosensor for detecting IL-6 with impedance spectroscopy has also been recently proposed for this purpose, although its performance in vivo has not been tested as of yet [51]. Recently, wearable biosensors capable of measuring several cytokines (IFN- $\gamma$, TNF- $\alpha$, and IL-6) in sweat were proposed in the context of COVID-19 care [101]. The biosensors used graphenebased field effect transistors integrated with microfluidics for sweat collection. The implementation of this nanomaterial enabled low limits of detection $\left(476 \times 10^{-15}, 608 \times 10^{-15}\right.$, and $611 \times 10^{-15} \mathrm{M}$, respectively) with a turnaround time within $7 \mathrm{~min}$. The signals generated by the biosensors were transmitted to smartphones (Fig. 4B). When combined with sweat induction using drugs like pilocarpine, these biosensors could enable a new paradigm in sepsis management based on the continuous monitoring of patient with wearable devices.

\section{Non-hospital environments}

\section{Ambulances}

Many sepsis patients arrive to hospitals in ambulances, where they are attended by a paramedic. It has been proposed that paramedics could provide a first evaluation of sepsis in order to avoid delays in antibiotic prescription. As in triage, this consists of a few measurements of vital constants, which has very low specificity towards sepsis diagnosis. Incorporating lactate measurements could help evaluate if the patients have a bad prognosis and bypass nurse triage to avoid delays in life-saving treatments. These only require puncturing a finger with a lancet and analyzing a drop of blood with a small, portable reader, which can be done in a moving vehicle. Yet, the performance of enzyme biosensors varies with temperature, and this parameter is not as controlled in an ambulance as it is in a hospital environment, which could yield misleading results.

Most previously proposed biosensors for measuring protein biomarkers would be difficult to implement in an ambulance, as the wobbly ride may have an impact on microfluidic systems, or the alignment of optical devices. 
For example, it is known that the distance and angle between the smartphone and the sensor have a great impact in densitometric analysis with mobile devices. Therefore, smartphone-based detection schemes would have to take into account the difficulties of focusing under unsteady conditions. A potential solution to this issue would be to implement paper transducers for colorimetric readout based on augmented reality. In this approach, a piece software uses a smartphone camera to recognize a pattern printed on a piece of paper. When the colorimetric signal is generated, the pattern blurs and recognition is blocked. Pattern recognition is less sensitive to changes in angle and distance than densitometric analysis, which makes more robust in this scenario $[35,102]$. This method can be used to develop an "on-off" optical switch that generates and augmented message depending on the levels of a particular biomarker. For example, it has been shown that this approach can be used to detect elevated levels of C-reactive protein via the visualization of a "CRP" message on the smartphone screen when coupled with a competitive immunoassay on magnetic beads (Fig. 5A) [35]. It has also been used to detect procalcitonin with paper biosensors [102] (Fig. 5B). Integrating these paper transducers with paper fluidics for automated detection [103] could enable the detection of sepsis biomarker in unsteady conditions like those encountered during the ride to the hospital.
Fig. 3 Examples of biosensors for measuring PCT in the ICU. A Plasmonic platform based in a sandwich immunoassay on a gold-covered glass chip. Streptavidin-coated gold nanoparticles interact with biotin and this binding is monitored with a plasmonic platform. Assay time is less than 25 min. Reproduced with permission from ref. [44] (American Chemical Society 2019). B This device uses a double enzyme reaction and measures the ATP-luciferinluciferase bioluminescent signal with a portable detector. In the presence of the analyte, the signal is inhibited and the bioluminescent signal decreases. Reproduced with permission from ref. [45] (American Chemical Society 2017)

\section{A)}

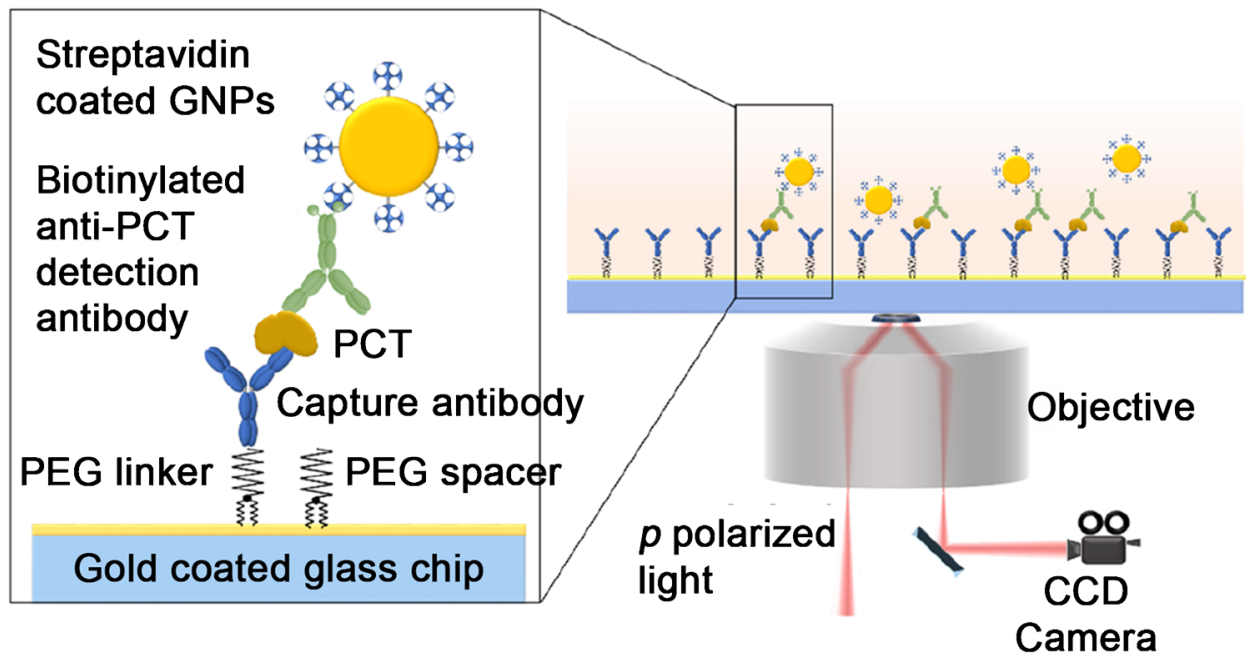

B)

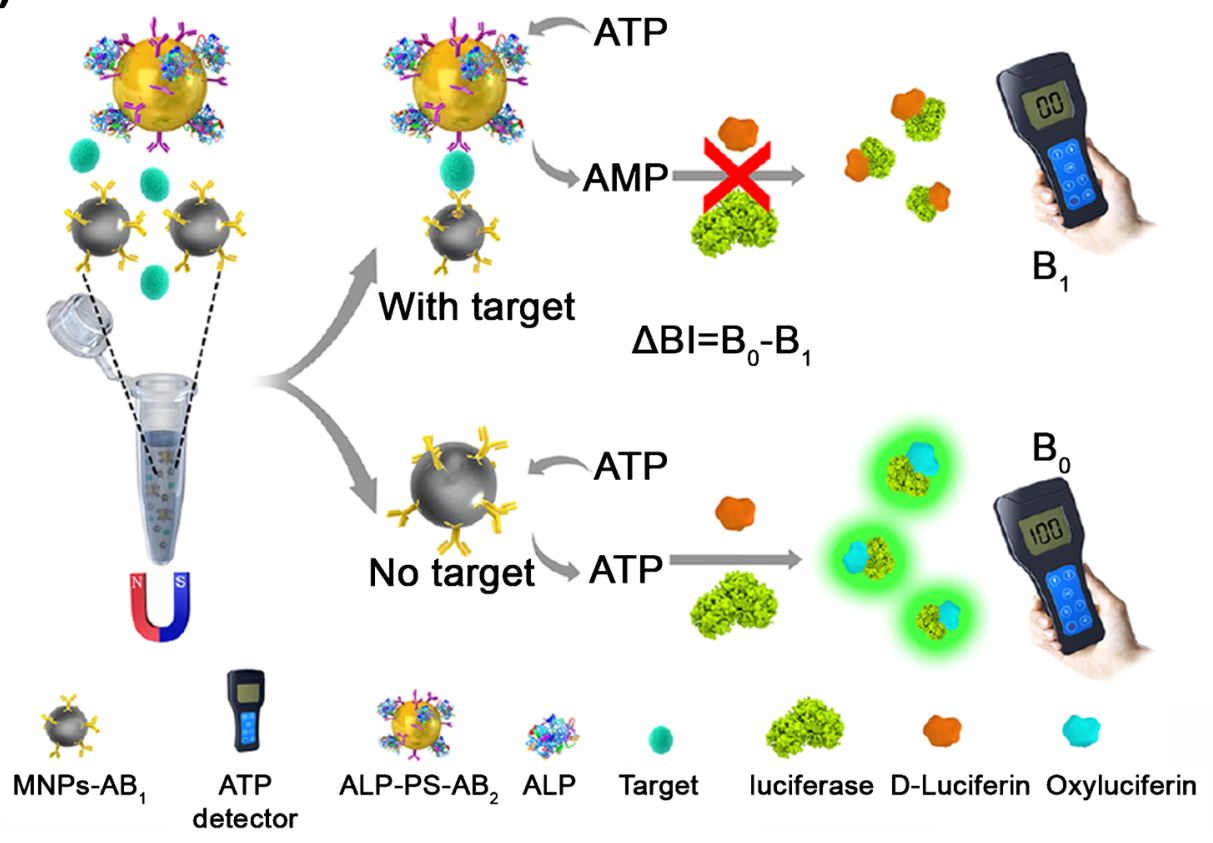



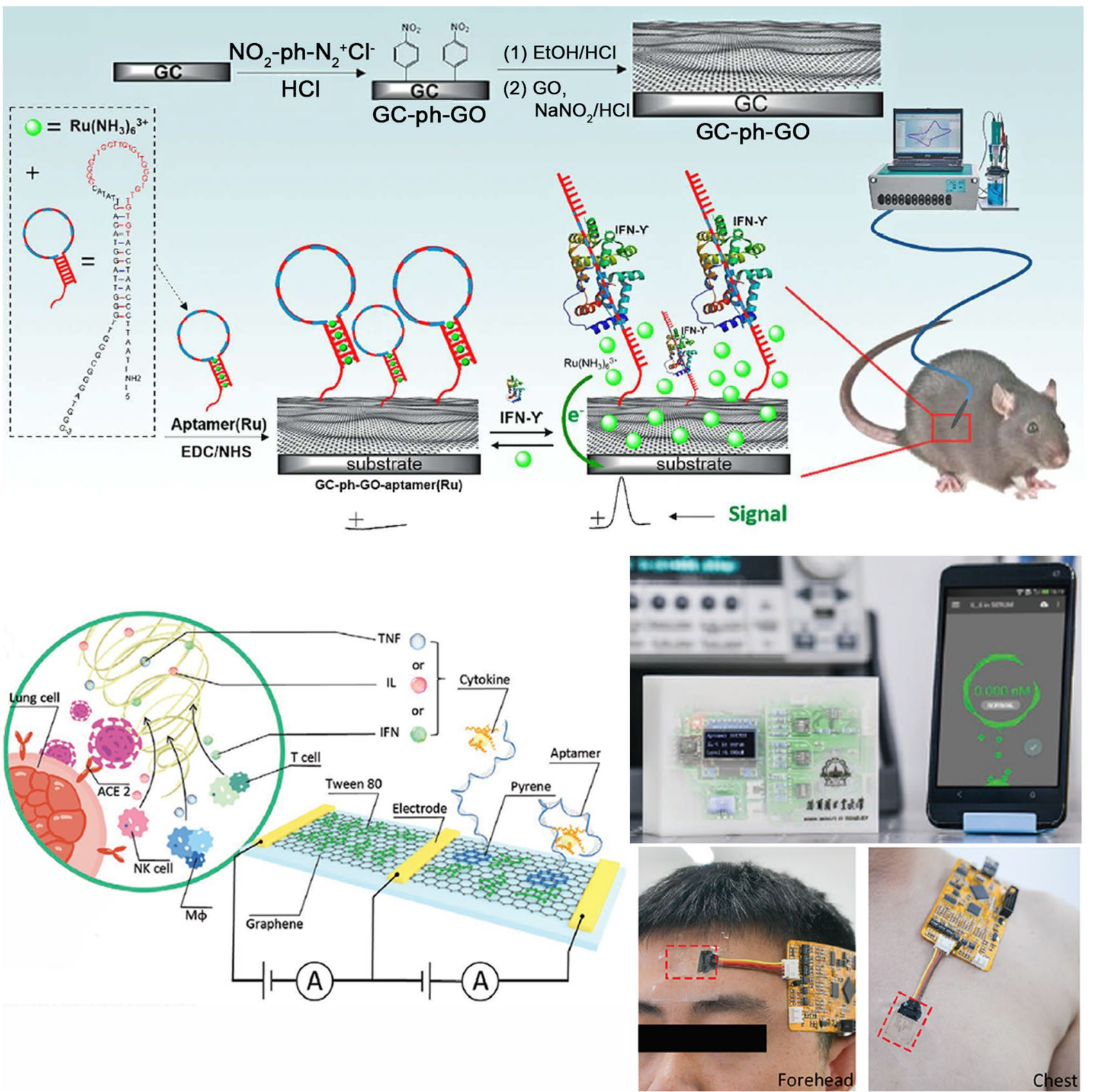

Fig. 4 Implantable biosensor for the real-time detection of cytokines. When IFN- $\gamma$ binds with the aptamer, it releases ruthenium complexes which generate an electrochemical signal. The device has a low limit of detection and is able to monitor mice in vivo during $48 \mathrm{~h}$. Reproduced with permission from ref. [46] (American Chemical Society

\section{Resource-limited settings}

Sepsis has a greater incidence in countries with less resources [1]. There, infections are often managed by a frontline healthcare worker with very limited access to diagnostic tests. In this scenario, decentralized approaches for detecting biomarkers could greatly help diagnosing sepsis.
2018). B Wearable biosensors for several cytokines detection. Sweat is collected using a microfluidic design and analyzed by graphenebased field effect transistors, which transfer the signal to smartphones. Adapted with permission from ref. [47] (John Wiley and Sons 2021)

These approaches will need to be not only inexpensive, but also extremely robust, since the detection will be performed in different humidity and temperature conditions.

Recently, an analytical platform was proposed that could meet this challenge [77]. It is based on measuring changes in the fluorescence emission of a multisensor upon the addition of serum. The multisensor contained gold and 
Fig. 5 Examples of smartphonebased detection using gold nanoparticles as colorimetric probes and augmented reality. A Use of the aggregation of gold nanoparticles in the presence of CRP to generate a positive signal (showed with a "CRP" message). Adapted with permission from ref. [49] (Elsevier 2018). B The same concept applied to the detection of PCT. In this case, three levels of PCT concentrations are stablished by a traffic light signal. Adapted with permission from ref. [48] (American Chemical Society 2018)
A) [CRP] $\left(\mathrm{g} \cdot \mathrm{mL}^{-1}\right)$

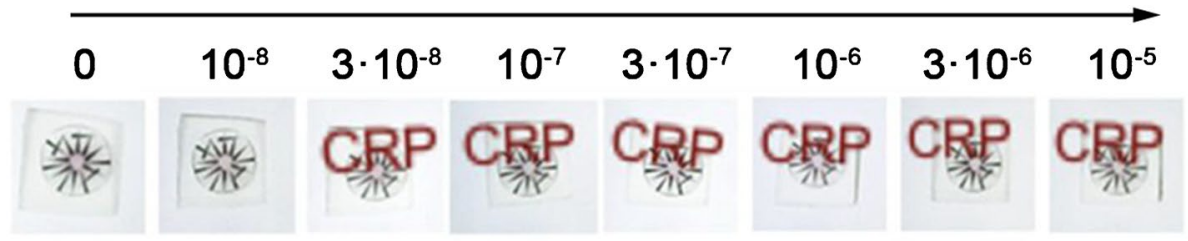

B)
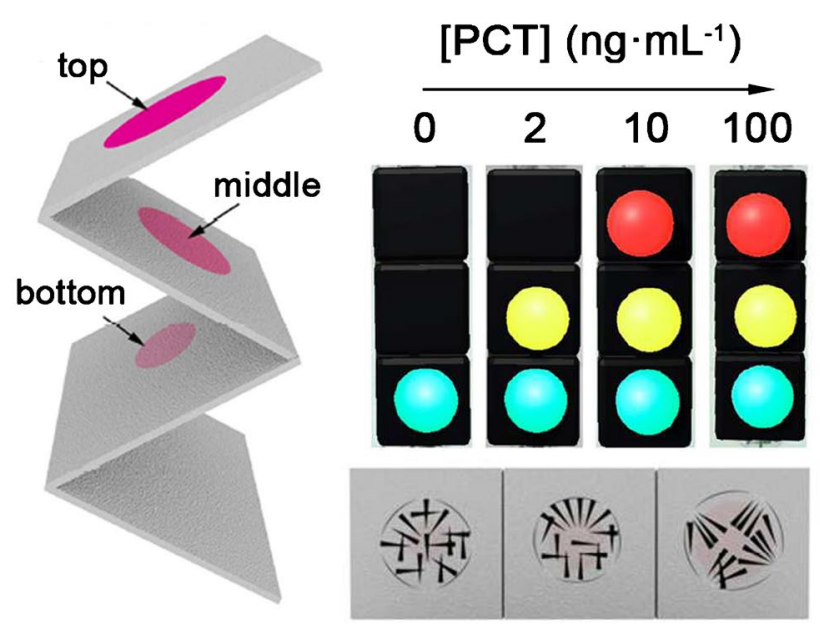

copper nanoclusters capped with different ligands. Sera of different composition change the fluorescence emission of the array in different ways, which is the basis for detecting bacteremia without using expensive and labile biorecognition elements. Signals are obtained by exciting the fluorophores with a handheld UV lamp and recording signals with a smartphone. It was shown that the sensor could diagnose septicemia when analyzing samples from 40 underage patients. This approach could be a real game changer for sepsis management if it proved to be specific enough to identify septic patients even in the presence of confounding factors (i.e., comorbidities).

\section{Conclusions and future directions}

Robust methods for the rapid detection of biomarkers are needed to manage severe infections. To minimize the timeto-diagnosis, this requires decentralized approaches suitable for biomarker detection at all the points where sepsis care is provided, from the ambulance to the emergency room and the ICU. Detecting multiple analytes simultaneously improves the diagnostic power of the analysis, as long as this can be performed in a timely manner. In order to produce diagnostic tools with real impact in patient care, analytical chemists must change focus from achieving the lowest limit of detection possible to measuring biomarker variations in the relevant clinical range with minimal effort and as rapidly as possible.
Magnetic particles are one of the most utilized microstructured materials for facilitating the rapid capture of biomarkers. Their large surface area and facile manipulation with a magnet has made them ideal components of fully automated systems for detecting sepsis biomarkers. They also enable capturing analytes in raw samples, which is important to reduce the time-to-diagnosis. With regard to multiplexing, most approaches have relied in using arrays of electrochemical transducers. Graphene is the most common nanostructured material used thus far to boost the sensitivity of these assays. Colorimetric approaches, which can leverage unmodified smartphones as signal readers, are advantageous for widespread decentralized measurements. Plasmonic nanoparticles are the most common nanosensors used in these approaches, although fluorimetric sensors using quantum dots have also been proposed.

Wearable biosensors could revolutionize sepsis care with a new paradigm for continuous patient monitoring. However, most wearable biosensors proposed so far are based on noninvasive measurements in body fluids such as saliva or sweat. Whereas these body fluids contain potential sepsis biomarkers such as cytokines and lactate, their predictive value in the context of sepsis care has not been validated as of yet. For example, IL-6 has been found in sweat but there is no proof that variations in sweat IL- 6 correlate with variations of serum IL-6. Sweat also contains lactate, but this could originate from muscle strain or from osmotic interchange with blood. Thus, new studies validating these biomarkers 
with large cohorts of patients should be performed. Invasive implanted biosensors could detect biomarker variations in blood, but they would require an exquisite performance to detect biomarkers in a single step and in such complex biological matrix. Advanced antifouling methods will be required to avoid non-specific signals in this scenario.

The recent COVID-19 pandemic has brought to light the social and economic relevance of severe infections and sepsis. The relentless advance of mechanisms of antimicrobial resistance is increasing the incidence of sepsis every year. New tools are required in order to improve patient care and reduce the enormous social and economic impact of this syndrome. Micro- and nanostructured materials can make this healthcare revolution possible by enabling new analytical platforms capable of rapid and decentralized sepsis diagnostics.

Supplementary Information The online version contains supplementary material available at https://doi.org/10.1007/s00604-022-05171-2.

Author contribution Alejandra Alba-Patiño: investigation, methodology; Enrique Barón: methodology, supervision, writing-review and editing; Andreu Vaquer: investigation, methodology; Steven M. Russell: investigation, methodology, writing-review and editing; Marcio Borges: methodology, resources; Roberto de la Rica: conceptualization, funding acquisition; investigation, project administration; resources; supervision, writing — original draft; writing — review and editing.

Funding Project PI20/0538 was funded by the Instituto de Salud Carlos III and co-funded by the European Union (ERDF, "A way to make Europe"). E. Barón: Sara Borrell contract (CD19/00140) from the Instituto de Salud Carlos III. R. de la Rica: Radix Fellowship from IdISBa/ Impost turisme sostenible/Agència d'Estratègia Turística de les Illes Balears/Govern de les Illes Balears. A. Alba-Patiño: "Stop fuga de cerebros" Fellowship (Roche).

Code availability Not applicable.

Availability of data and material (data transparency) Not applicable.

\section{Declarations}

Ethics approval Not applicable.

Consent to participate Not applicable.

Consent for publication Not applicable.

Competing interests The authors declare no competing interests.

\section{References}

1. Rudd KE, Johnson SC, Agesa KM et al (2020) Global, regional, and national sepsis incidence and mortality, 1990-2017: analysis for the Global Burden of Disease Study. Lancet 395:200-211. https://doi.org/10.1016/S0140-6736(19)32989-7
2. Singer M, Deutschman CS, Seymour C et al (2016) The third international consensus definitions for sepsis and septic shock (sepsis-3). JAMA - J Am Med Assoc 315:801-810. https://doi. org/10.1001/jama.2016.0287

3. Rhodes A, Evans LE, Alhazzani W et al (2017) Surviving Sepsis Campaign: international guidelines for management of sepsis and septic shock: 2016. Springer, Berlin Heidelberg

4. Nunnally ME, Ferrer R, Martin GS et al (2021) (2021) The Surviving Sepsis Campaign: research priorities for the administration, epidemiology, scoring and identification of sepsis. Intensive Care Med Exp 91(9):1-26. https://doi.org/10.1186/ S40635-021-00400-Z

5. Henriquez-Camacho C, Losa J (2014) Biomarkers for sepsis. Biomed Res Int 2014:.https://doi.org/10.1155/2014/547818

6. El Haddad H, Chaftari AM, Hachem R et al (2018) Biomarkers of sepsis and bloodstream infections: the role of procalcitonin and proadrenomedullin with emphasis in patients with cancer. Clin Infect Dis 67:971-977. https://doi.org/10.1093/cid/ciy331

7. Limper M, de Kruif MD, Duits AJ et al (2010) The diagnostic role of procalcitonin and other biomarkers in discriminating infectious from non-infectious fever. J Infect 60:409-416. https:// doi.org/10.1016/j.jinf.2010.03.016

8. Kumar S, Tripathy S, Jyoti A, Singh SG (2019) Recent advances in biosensors for diagnosis and detection of sepsis: a comprehensive review. Biosens Bioelectron 124-125:205-215. https://doi. org/10.1016/j.bios.2018.10.034

9. Reddy B Jr, Hassan U, Seymour C et al (2018) Point-of-care sensors for the management of sepsis. Nat Biomed Eng 2:640-648. https://doi.org/10.1038/s41551-018-0288-9

10. Leonard H, Colodner R, Halachmi S, Segal E (2018) Recent advances in the race to design a rapid diagnostic test for antimicrobial resistance. ACS Sensors 3:2202-2217. https://doi.org/10. 1021/ACSSENSORS.8B00900

11. Zhou Y, Wang Z, Peng Y et al (2021) Gold nanomaterials as a promising integrated tool for diagnosis and treatment of pathogenic infections-a review. J Biomed Nanotechnol 17:744-770. https://doi.org/10.1166/JBN.2021.3075

12. Deusenbery C, Wang Y, Shukla A (2021) Recent innovations in bacterial infection detection and treatment. ACS Infect Dis 7:695-720. https://doi.org/10.1021/ACSINFECDIS.0C00890

13. Wongkaew N, Simsek M, Griesche C, Baeumner AJ (2019) Functional nanomaterials and nanostructures enhancing electrochemical biosensors and lab-on-a-chip performances: recent progress, applications, and future perspective. Chem Rev 119:120-194. https://doi.org/10.1021/acs.chemrev.8b00172

14. Tang CK, Vaze A, Shen M, Rusling JF (2016) High-throughput electrochemical microfluidic immunoarray for multiplexed detection of cancer biomarker proteins. ACS Sensors 1:1036-1043. https://doi.org/10.1021/acssensors.6b00256

15. Dagar K, Pundir CS (2017) An improved amperometric L-lactate biosensor based on covalent immobilization of microbial lactate oxidase onto carboxylated multiwalled carbon nanotubes/copper nanoparticles/polyaniline modified pencil graphite electrode. Enzyme Microb Technol 96:177-186. https://doi.org/10.1016/j. enzmictec.2016.10.014

16. Lamas-Ardisana PJ, Loaiza OA, Añorga L et al (2014) Disposable amperometric biosensor based on lactate oxidase immobilised on platinum nanoparticle-decorated carbon nanofiber and poly(diallyldimethylammonium chloride) films. Biosens Bioelectron 56:345-351. https://doi.org/10.1016/j.bios.2014.01.047

17. Molinero-Fernández Á, Arruza L, López MÁ, Escarpa A (2020) On-the-fly rapid immunoassay for neonatal sepsis diagnosis: C-reactive protein accurate determination using magnetic graphene-based micromotors. Biosens Bioselectron 158:112156. https://doi.org/10.1016/j.bios.2020.112156 
18. Vokhmyanina DV, Andreeva KD, Komkova MA et al (2020) 'Artificial peroxidase' nanozyme - enzyme based lactate biosensor. Talanta 208:120393. https://doi.org/10.1016/j.talanta.2019. 120393

19. Bravo I, Gutiérrez-Sánchez C, García-Mendiola T et al (2019) Enhanced performance of reagent-less carbon nanodots based enzyme electrochemical biosensors. Sensors (Switzerland) 19:5576. https://doi.org/10.3390/s19245576

20. Ghrera AS (2019) Quantum dot modified interface for electrochemical immunosensing of procalcitonin for the detection of urinary tract infection. Anal Chim Acta 1056:26-33. https://doi. org/10.1016/j.aca.2018.12.047

21. Molinero-Fernández Á, Moreno-Guzmán M, Arruza L et al (2019) Toward early diagnosis of late-onset sepsis in preterm neonates: dual magnetoimmunosensor for simultaneous procalcitonin and C-reactive protein determination in diagnosed clinical samples. ACS Sensors 4:2117-2123. https://doi.org/10.1021/ acssensors.9b00890

22. Molinero-Fernández Á, Moreno-Guzmán M, López MÁ, Escarpa A (2020) Magnetic bead-based electrochemical immunoassays on-drop and on-chip for procalcitonin determination: disposable tools for clinical sepsis diagnosis. Biosensors 10:.https://doi.org/ 10.3390/BIOS10060066

23. Molinero-Fernández Á, López MÁ, Escarpa A (2020) An onchip microfluidic-based electrochemical magneto-immunoassay for the determination of procalcitonin in plasma obtained from sepsis diagnosed preterm neonates. Analyst 145:5004-5010. https://doi.org/10.1039/d0an00624f

24. Tertis M, Leva PI, Bogdan D et al (2019) Impedimetric aptasensor for the label-free and selective detection of interleukin- 6 for colorectal cancer screening. Biosens Bioelectron 137:123-132. https://doi.org/10.1016/j.bios.2019.05.012

25. Zhang K, Liu G, Goldys EM (2018) Robust immunosensing system based on biotin-streptavidin coupling for spatially localized femtogram $\mathrm{mL}-1$ level detection of interleukin-6. Biosens Bioelectron 102:80-86. https://doi.org/10.1016/j.bios.2017.11. 023

26. Manna B, Retna Raj C (2016) Covalent functionalization and electrochemical tuning of reduced graphene oxide for the bioelectrocatalytic sensing of serum lactate. J Mater Chem B 4:45854593. https://doi.org/10.1039/c6tb00721j

27. Hashemzadeh S, Omidi Y, Rafii-Tabar H (2019) Amperometric lactate nanobiosensor based on reduced graphene oxide, carbon nanotube and gold nanoparticle nanocomposite. Microchim Acta 186:1-8. https://doi.org/10.1007/s00604-019-3791-0

28. Azzouzi S, Rotariu L, Benito AM et al (2015) A novel amperometric biosensor based on gold nanoparticles anchored on reduced graphene oxide for sensitive detection of 1-lactate tumor biomarker. Biosens Bioelectron 69:280-286. https://doi.org/10. 1016/j.bios.2015.03.012

29. Fang Y, Hu Q, Yu X, Wang L (2018) Ultrasensitive electrochemical immunosensor for procalcitonin with signal enhancement based on zinc nanoparticles functionalized ordered mesoporous carbon-silica nanocomposites. Sensors Actuators, B Chem 258:238-245. https://doi.org/10.1016/j.snb.2017.11.062

30. Wei H, Ni S, Cao C et al (2018) Graphene oxide signal reporter based multifunctional immunosensing platform for amperometric profiling of multiple cytokines in serum. ACS Sensors 3:15531561. https://doi.org/10.1021/acssensors.8b00365

31. Çelik AC, Öztürk F, Erden PE et al (2015) Amperometric lactate biosensor based on carbon paste electrode modified with benzo[c]cinnoline and multiwalled carbon nanotubes. Electroanalysis 27:2820-2828. https://doi.org/10.1002/elan.201500180

32. Chen YT, Lee YC, Lai YH et al (2020) Review of integrated optical biosensors for point-of-care applications. Biosensors 10:1-22. https://doi.org/10.3390/bios 10120209
33. Chen C, Wang J (2020) Optical biosensors: an exhaustive and comprehensive review. Analyst 145:1605-1628. https://doi.org/ 10.1039/c9an01998g

34. Yin B, Zheng W, Dong M et al (2017) An enzyme-mediated competitive colorimetric sensor based on Au@Ag bimetallic nanoparticles for highly sensitive detection of disease biomarkers. Analyst 142:2954-2960. https://doi.org/10.1039/c7an00779e

35. Russell SM, de la Rica R (2018) Paper transducers to detect plasmon variations in colorimetric nanoparticle biosensors. Sensors Actuators, B Chem 270:327-332. https://doi.org/10.1016/J.SNB. 2018.05.052

36. Wu B, Jiang R, Wang Q et al (2016) Detection of C-reactive protein using nanoparticle-enhanced surface plasmon resonance using an aptamer-antibody sandwich assay. Chem Commun 52:3568-3571. https://doi.org/10.1039/c5cc10486f

37. Zhu J, He J, Verano M et al (2018) An integrated adipose-tissue-on-chip nanoplasmonic biosensing platform for investigating obesity-associated inflammation. Lab Chip 18:3550-3560. https://doi.org/10.1039/c8lc00605a

38. Aydın EB, Aydın M, Sezgintürk MK (2020) The development of an ultra-sensitive electrochemical immunosensor using a PPyrNHS functionalized disposable ITO sheet for the detection of interleukin 6 in real human serums. New J Chem. https://doi.org/ 10.1039/d0nj03183f

39. Guo J, Zhang J, Tian S et al (2021) An up conversion optical system based on mesoporous silica encapsulated up-converting nanoparticles labeled lateral flow immunoassay for procalcitonin quantification in Plasma. IEEE J Sel Top Quantum Electron 27:1-7. https://doi.org/10.1109/JSTQE.2021.3060496

40. Molinero-Fernández Á, Moreno-Guzmán M, Arruza L et al (2020) Polymer-based micromotor fluorescence immunoassay for on-the-move sensitive procalcitonin determination in very low birth weight infants' plasma. ACS Sensors 5:1336-1344. https://doi.org/10.1021/acssensors.9b02515

41. Molinero-Fernandez A, Lopez MA, Escarpa A (2020) Electrochemical microfluidic micromotors-based immunoassay for C-reactive protein determination in preterm neonatal samples with sepsis suspicion. Anal Chem 92:5048-5054. https://doi.org/ 10.1021/acs.analchem.9b05384

42. Rassaei L, Olthuis W, Tsujimura S et al (2014) Lactate biosensors: current status and outlook. Anal Bioanal Chem 406:123137. https://doi.org/10.1007/s00216-013-7307-1

43. Pundir CS, Narwal V, Batra B (2016) Determination of lactic acid with special emphasis on biosensing methods: a review. Biosens Bioelectron 86:777-790. https://doi.org/10.1016/j.bios.2016.07. 076

44. Rhee C, Murphy MV, Li L et al (2017) Lactate testing in suspected sepsis: trends and predictors of failure to measure levels. Crit Care Med 43:1669-1676. https://doi.org/10.1186/s40945017-0033-9.Using

45. Meynaar IA, Droog W, Batstra M et al (2011) In critically ill patients, serum procalcitonin is more useful in differentiating between sepsis and SIRS than CRP, Il-6, or LBP. Crit Care Res Pract 2011:594645. https://doi.org/10.1155/2011/594645

46. Nakajima A, Yazawa J, Sugiki D et al (2014) Clinical utility of procalcitonin as a marker of sepsis: a potential predictor of causative pathogens. Intern Med 53:1497-1503. https://doi.org/ 10.2169/internalmedicine.53.1785

47. Rhodes A, Evans LE, Alhazzani W, et al (2017) Surviving Sepsis Campaign: international guidelines for management of sepsis and septic shock: 2016

48. Hou T, Huang D, Zeng R et al (2015) Accuracy of serum interleukin (IL)-6 in sepsis diagnosis: a systematic review and metaanalysis. Int J Clin Exp Med 8:15238-15245. https://doi.org/10. 1371/journal.pone.0133057 
49. Huang D, Ying H, Jiang D et al (2020) Rapid and sensitive detection of interleukin-6 in serum via time-resolved lateral flow immunoassay. Anal Biochem 588:113468. https://doi.org/ 10.1016/j.ab.2019.113468

50. Diacci C, Berto M, Di Lauro M et al (2017) Label-free detection of interleukin-6 using electrolyte gated organic field effect transistors. Biointerphases 12:05F401. https://doi.org/ $10.1116 / 1.4997760$

51. Russell C, Ward AC, Vezza V et al (2019) Development of a needle shaped microelectrode for electrochemical detection of the sepsis biomarker interleukin-6 (IL-6) in real time. Biosens Bioelectron 126:806-814. https://doi.org/10.1016/j.bios.2018. 11.053

52. Doellner H, Arntzen KJ, Haereid PE et al (1998) Interleukin-6 concentrations in neonates evaluated for sepsis. J Pediatr 132:295-299. https://doi.org/10.1016/S0022-3476(98)70448-2

53. Clyne B, Olshaker JS (1999) The C-reactive protein. J Emerg Med 17:1019-1025. https://doi.org/10.1016/S0736-4679(99) 00135-3

54. Póvoa P, Coelho L, Almeida E et al (2005) C-reactive protein as a marker of infection in critically ill patients. Clin Microbiol Infect 11:101-108. https://doi.org/10.1111/j.1469-0691.2004. 01044.x

55. Sharma D, Farahbakhsh N, Shastri S, Sharma P (2018) Biomarkers for diagnosis of neonatal sepsis: a literature review. J Matern Neonatal Med 31:1646-1659. https://doi.org/10.1080/14767058. 2017.1322060

56. Fabri-Faja N, Calvo-Lozano O, Dey P et al (2019) Early sepsis diagnosis via protein and miRNA biomarkers using a novel point-of-care photonic biosensor. Anal Chim Acta 1077:232242. https://doi.org/10.1016/j.aca.2019.05.038

57. Schmit X, Vincent JL (2008) The time course of blood C-reactive protein concentrations in relation to the response to initial antimicrobial therapy in patients with sepsis. Infection 36:213-219. https://doi.org/10.1007/s15010-007-7077-9

58. Önal U, Valenzuela-Sánchez F, Vandana K, Rello J (2018) Midregional pro-adrenomedullin (MR-proADM) as a biomarker for sepsis and septic shock: narrative review. Healthcare 6:110. https://doi.org/10.3390/healthcare6030110

59. Spoto S, Cella E, De Cesaris M et al (2018) Procalcitonin and MR-proadrenomedullin combination with SOFA and qSOFA scores for sepsis diagnosis and prognosis: a diagnostic algorithm. Shock 50:44-52. https://doi.org/10.1097/SHK.00000 00000001023

60. Ulla M, Pizzolato E, Lucchiari M et al (2013) Diagnostic and prognostic value of presepsin in the management of sepsis in the emergency department: a multicenter prospective study. Crit Care 17:R168. https://doi.org/10.1186/cc12847

61. Battista S, Audisio U, Galluzzo C, et al (2016) Assessment of diagnostic and prognostic role of copeptin in the clinical setting of sepsis. Biomed Res Int 2016:.https://doi.org/10.1155/2016/ 3624730

62. Donadello K, Scolletta S, Covajes C, Vincent J-L (2012) suPAR as a prognostic biomarker in sepsis. BMC Med 10:2. https://doi. org/10.1186/1741-7015-10-2

63. Wu CC, Lan HM, Han ST et al (2017) Comparison of diagnostic accuracy in sepsis between presepsin, procalcitonin, and C-reactive protein: a systematic review and meta-analysis. Ann Intensive Care 7:1-16. https://doi.org/10.1186/S13613-017-0316-Z/ FIGURES/7

64. Ulla M, Pizzolato E, Lucchiari M et al (2013) Diagnostic and prognostic value of presepsin in the management of sepsis in the emergency department: a multicenter prospective study. Crit Care 17:1-8. https://doi.org/10.1186/CC12847/FIGURES/3

65. Su L, Xie L, Liu D (2015) Urine sTREM-1 may be a valuable biomarker in diagnosis and prognosis of sepsis-associated acute kidney injury. Crit Care 19:1-3. https://doi.org/10.1186/S13054015-0998-2/FIGURES/1

66. El-Din AN, Abdel-Gawad AR, Abdelgalil W, Fahmy NF (2021) Evaluation of sTREM1 and suPAR biomarkers as diagnostic and prognostic predictors in sepsis patients. Infect Drug Resist 14:3495-3507. https://doi.org/10.2147/IDR.S314237

67. Ramis JM (2020) (2020) Extracellular vesicles in cell biology and medicine. Sci Reports 101(10):1-2. https://doi.org/10.1038/ s41598-020-65826-z

68. Neubacher S, Arenz C (2009) Rolling-circle amplification: unshared advantages in miRNA detection. ChemBioChem 10:1289-1291. https://doi.org/10.1002/CBIC.200900116

69. Saadat A, Huyke DA, Oyarzun DI et al (2020) A system for the high-throughput measurement of the shear modulus distribution of human red blood cells. Lab Chip 20:2927-2936. https://doi. org/10.1039/D0LC00283F

70. Ellett F, Jorgensen J, Marand AL et al (2018) (2018) Diagnosis of sepsis from a drop of blood by measurement of spontaneous neutrophil motility in a microfluidic assay. Nat Biomed Eng 24(2):207-214. https://doi.org/10.1038/s41551-018-0208-z

71. Hassan U, Ghonge T, Reddy B et al (2017) (2017) A point-ofcare microfluidic biochip for quantification of CD64 expression from whole blood for sepsis stratification. Nat Commun 81(8):112. https://doi.org/10.1038/ncomms15949

72. Santopolo G, Clemente A, Aranda M, et al (2021) Colorimetric detection of sepsis-derived hyperdegranulation with plasmonic nanosensors. ACS Sensors acssensors.1c01884. https://doi.org/ 10.1021/ACSSENSORS.1C01884

73. Nomura F, Tsuchida S, Murata S et al (2020) Mass spectrometrybased microbiological testing for blood stream infection. Clin Proteomics 17:1-11. https://doi.org/10.1186/S12014-020-092787/TABLES/2

74. Dey P, Fabri-Faja N, Calvo-Lozano O et al (2019) Label-free bacteria quantification in blood plasma by a bioprinted microarray based interferometric point-of-care device. ACS Sensors 4:52-60. https://doi.org/10.1021/acssensors.8b00789

75. Mou XZ, Chen XY, Wang J et al (2019) Bacteria-instructed click chemistry between functionalized gold nanoparticles for point-of-care microbial detection. ACS Appl Mater Interfaces 11:23093-23101. https://doi.org/10.1021/acsami.9b09279

76. Dow P, Kotz K, Gruszka S et al (2018) Acoustic separation in plastic microfluidics for rapid detection of bacteria in blood using engineered bacteriophage. Lab Chip 18:923-932. https://doi.org/ $10.1039 / \mathrm{c} 71 \mathrm{c} 01180 \mathrm{f}$

77. Sheini A (2021) A point-of-care testing sensor based on fluorescent nanoclusters for rapid detection of septicemia in children. Sensors Actuators B Chem 328:129029. https://doi.org/ 10.1016/J.SNB.2020.129029

78. Narayana Iyengar S, Dietvorst J, Ferrer-Vilanova A et al (2021) Toward rapid detection of viable bacteria in whole blood for early sepsis diagnostics and susceptibility testing. ACS Sensors 6:3357-3366. https://doi.org/10.1021/acssensors.1c01219

79. Park C, Kong M, Lee JH et al (2018) Detection of Bacillus Cereus using bioluminescence assay with cell wall-binding domain conjugated magnetic nanoparticles. Biochip J 12:287293. https://doi.org/10.1007/s13206-018-2408-8

80. Kang DK, Ali MM, Zhang K et al (2014) Rapid detection of single bacteria in unprocessed blood using Integrated Comprehensive Droplet Digital Detection. Nat Commun 5:1-10. https:// doi.org/10.1038/ncomms6427

81. Yuan K, Mei Q, Guo X et al (2018) Antimicrobial peptide based magnetic recognition elements and Au@Ag-GO SERS tags with stable internal standards: a three in one biosensor for isolation, discrimination and killing of multiple bacteria in whole blood. Chem Sci 9:8781-8795. https://doi.org/10.1039/c8sc04637a 
82. Pazos-Perez N, Pazos E, Catala C et al (2016) Ultrasensitive multiplex optical quantification of bacteria in large samples of biofluids. Sci Rep 6:1-10. https://doi.org/10.1038/srep29014

83. Lee CW, Chang HY, Wu JK, Tseng FG (2019) Ultra-sensitive electrochemical detection of bacteremia enabled by redoxactive gold nanoparticles (raGNPs) in a nano-sieving microfluidic system (NS-MFS). Biosens Bioelectron 133:215-222. https://doi.org/10.1016/j.bios.2019.03.040

84. Jiménez AJ, Supino M, López Tapia JD et al (2019) Sepsis in the emergency department: key points, controversies, and proposals for improvements in Latin America. Emergencias 31:123-135

85. Soremekun OA, Datner EM, Banh S et al (2013) Utility of pointof-care testing in ED triage. Am J Emerg Med 31:291-296. https://doi.org/10.1016/j.ajem.2012.07.025

86. Singer M, Deutschman CS, Seymour C et al (2016) The Third International Consensus Definitions for Sepsis and Septic Shock (Sepsis-3). JAMA 315:801-810. https://doi.org/10.1001/JAMA. 2016.0287

87. Sager R, Wirz Y, Amin D et al (2017) Are admission procalcitonin levels universal mortality predictors across different medical emergency patient populations? Results from the multi-national, prospective, observational TRIAGE study. Clin Chem Lab Med 55:1873-1880. https://doi.org/10.1515/ cclm-2017-0144

88. Desautels T, Calvert J, Hoffman J, et al (2016) Prediction of sepsis in the intensive care unit with minimal electronic health record data: a machine learning approach. JMIR Med informatics 4:.https://doi.org/10.2196/MEDINFORM.5909

89. Kwon YS, Baek MS (2020) Development and validation of a quick sepsis-related organ failure assessment-based machinelearning model for mortality prediction in patients with suspected infection in the emergency department. J Clin Med 2020 9:875. https://doi.org/10.3390/JCM9030875

90. Schenz J, Weigand MA, Uhle F (2019) Molecular and biomarkerbased diagnostics in early sepsis: current challenges and future perspectives. 19:1069-1078.https://doi.org/10.1080/14737159. 2020.1680285

91. Russell SM, Alba-Patiño A, Borges M, de la Rica R (2019) Multifunctional motion-to-color janus transducers for the rapid detection of sepsis biomarkers in whole blood. Biosens Bioelectron 140:111346. https://doi.org/10.1016/j.bios.2019.111346

92. Borse V, Srivastava R (2019) Fluorescence lateral flow immunoassay based point-of-care nanodiagnostics for orthopedic implant-associated infection. Sensors Actuators, B Chem 280:24-33. https://doi.org/10.1016/j.snb.2018.10.034

93. Adrover-Jaume C, Alba-Patiño A, Clemente A et al (2021) Paper biosensors for detecting elevated IL-6 levels in blood and respiratory samples from COVID-19 patients. Sensors Actuators, B Chem 330:129333. https://doi.org/10.1016/j.snb.2020.129333

94. Alba-Patiño A, Russell SM, Borges M et al (2020) Nanoparticlebased mobile biosensors for the rapid detection of sepsis biomarkers in whole blood. Nanoscale Adv 2:1253-1260. https:// doi.org/10.1039/D0NA00026D

95. Min J, Nothing M, Coble B et al (2018) Integrated biosensor for rapid and point-of-care sepsis diagnosis. ACS Nano 12:33783384. https://doi.org/10.1021/acsnano.7b08965

96. Taneja I, Reddy B, Damhorst G et al (2017) (2017) Combining biomarkers with EMR data to identify patients in different phases of sepsis. Sci Reports 71(7):1-12. https://doi.org/10.1038/ s41598-017-09766-1

97. Chen P, Chung MT, McHugh W et al (2015) Multiplex serum cytokine immunoassay using nanoplasmonic biosensor microarrays. ACS Nano 9:4173-4181. https://doi.org/10.1021/acsnano. 5 b00396
98. Jing W, Wang Y, Yang Y et al (2019) Time-resolved digital immunoassay for rapid and sensitive quantitation of procalcitonin with plasmonic imaging. ACS Nano 13:8609-8617. https://doi. org/10.1021/acsnano.9b02771

99. Chen Y, Xianyu Y, Wu J et al (2017) Double-enzymes-mediated bioluminescent sensor for quantitative and ultrasensitive pointof-care testing. Anal Chem 89:5422-5427. https://doi.org/10. 1021/acs.analchem.7b00239

100. Cao C, Jin R, Wei $\mathrm{H}$ et al (2018) Graphene oxide based recyclable in vivo device for amperometric monitoring of interferon- $\gamma$ in inflammatory mice. ACS Appl Mater Interfaces 10:3307833087. https://doi.org/10.1021/acsami.8b13518

101. Hao Z, Luo Y, Huang C et al (2021) An intelligent graphenebased biosensing device for cytokine storm syndrome biomarkers detection in human biofluids. Small 17:1-11. https://doi.org/10. 1002/smll.202101508

102. Russell SM, Alba-Patiño A, Borges M, de la Rica R (2018) A robust and user-friendly alternative to densitometry using origami biosensors and digital logic. ACS Sensors 3:1712-1718. https://doi.org/10.1021/acssensors.8b00452

103. Fu H, Song P, Wu Q, et al (2019) A paper-based microfluidic platform with shape-memory-polymer-actuated fluid valves for automated multi-step immunoassays. Microsystems Nanoeng 5:.https://doi.org/10.1038/s41378-019-0091-0

104. Hirst NA, Hazelwood LD, Jayne DG, Millner PA (2013) An amperometric lactate biosensor using $\mathrm{H} 2 \mathrm{O} 2$ reduction via a Prussian Blue impregnated poly(ethyleneimine) surface on screen printed carbon electrodes to detect anastomotic leak and sepsis. Sensors Actuators, B Chem 186:674-680. https://doi.org/10. 1016/j.snb.2013.06.090

105. Hickey DP, Reid RC, Milton RD, Minteer SD (2016) A selfpowered amperometric lactate biosensor based on lactate oxidase immobilized in dimethylferrocene-modified LPEI. Biosens Bioelectron 77:26-31. https://doi.org/10.1016/j.bios.2015.09.013

106. Uzunoglu A, Ramirez I, Andreasen E, Stanciu LA (2016) Layer by layer construction of ascorbate interference-free amperometric lactate biosensors with lactate oxidase, ascorbate oxidase, and ceria nanoparticles. Microchim Acta 183:1667-1675. https://doi. org/10.1007/s00604-016-1796-5

107. Boobphahom S, Rattanawaleedirojn P, Boonyongmaneerat $Y$ et al (2019) $\mathrm{TiO} 2 \mathrm{sol} /$ graphene modified 3D porous Ni foam: a novel platform for enzymatic electrochemical biosensor. J Electroanal Chem 833:133-142. https://doi.org/10.1016/j.jelechem. 2018.11.031

108. Kucherenko IS, Soldatkin OO, Topolnikova YV et al (2019) Novel multiplexed biosensor system for the determination of lactate and pyruvate in blood serum. Electroanalysis 31:1625-1631. https://doi.org/10.1002/elan.201900229

109. Zheng H, Zhang S, Liu X et al (2020) Synthesis of a PEDOT$\mathrm{TiO} 2$ heterostructure as a dual biosensing platform operating via photoelectrochemical and electrochemical transduction mode. Biosens Bioelectron 162:112234. https://doi.org/10.1016/j.bios. 2020.112234

110. Nesakumar N, Sethuraman S, Krishnan UM, Rayappan JBB (2013) Fabrication of lactate biosensor based on lactate dehydrogenase immobilized on cerium oxide nanoparticles. J Colloid Interface Sci 410:158-164. https://doi.org/10.1016/j.jcis.2013. 08.009

111. Batra B, Narwal V, Pundir CS (2016) An amperometric lactate biosensor based on lactate dehydrogenase immobilized onto graphene oxide nanoparticles modified pencil graphite electrode. Eng Life Sci 16:786-794. https://doi.org/10.1002/elsc.20160 0082.This

112. Narwal V, Sharma M, Rani S, Pundir CS (2018) An ultrasensitive amperometric determination of lactate by lactate dehydrogenase 
nanoparticles immobilized onto Au electrode. Int J Biol Macromol 115:767-775. https://doi.org/10.1016/j.ijbiomac.2018.04. 114

113. Cheng H, Hu C, Ji Z et al (2018) A solid ionic lactate biosensor using doped graphene-like membrane of Au-EVIMC-titania nanotubes-polyaniline. Biosens Bioelectron 118:97-101. https:// doi.org/10.1016/j.bios.2018.07.031

114. Shankara Narayanan J, Slaughter G (2020) Lactic acid biosensor based on lactate dehydrogenase immobilized on Au nanoparticle modified microwire electrode. IEEE Sens J 20:40344040. https://doi.org/10.1109/JSEN.2019.2963405

115. Promsuwan K, Meng L, Suklim P et al (2020) Bio-PEDOT: modulating carboxyl moieties in poly $(3,4$-ethylenedioxythiophene) for enzyme-coupled bioelectronic interfaces. ACS Appl Mater Interfaces 12:39841-39849. https://doi.org/10.1021/ acsami.0c 10270

116. Maduraiveeran G, Chen A (2021) Design of an enzyme-mimicking NiO@Au nanocomposite for the sensitive electrochemical detection of lactic acid in human serum and urine. Electrochim Acta 368:137612. https://doi.org/10.1016/j.electacta. 2020.137612

117. Huang YS, Chen KY, Cheng YT et al (2020) An inkjet-printed flexible non-enzymatic lactate sensor for clinical blood plasma Test. IEEE Electron Device Lett 41:597-600. https://doi.org/ 10.1109/LED.2020.2973343

118. QilinLi ZY, Fan H et al (2021) In vitro and in vivo detection of lactate with nanohybrid-functionalized Pt microelectrode facilitating assessment of tumor development. Biosens Bioelectron 191:113474. https://doi.org/10.1016/j.bios.2021.113474

119. Li F, Liu J, Guo L et al (2019) High-resolution temporally resolved chemiluminescence based on double-layered 3D microfluidic paper-based device for multiplexed analysis. Biosens Bioelectron 141:111472. https://doi.org/10.1016/j.bios. 2019.111472

120. Duong HD, Il RJ (2021) Ratiometric fluorescent biosensors for glucose and lactate using an oxygen-sensing membrane. Biosensors 11:208. https://doi.org/10.3390/bios11070208

121. Schuck A, Kim HE, Moreira JK et al (2021) A graphene-based enzymatic biosensor using a common-gate field-effect transistor for 1-lactic acid detection in blood plasma samples. Sensors 21:1-13. https://doi.org/10.3390/s21051852

122. Cao Q, Liang B, Yu C et al (2020) High accuracy determination of multi metabolite by an origami-based coulometric electrochemical biosensor. J Electroanal Chem 873:114358. https://doi. org/10.1016/j.jelechem.2020.114358

123. Panneer Selvam A, Prasad S (2017) Companion and Point-OfCare Sensor System For Rapid Multiplexed Detection Of A Panel Of Infectious Disease Markers. SLAS Technol 22:338-347. https://doi.org/10.1177/2211068217696779

124. Liu J, Quan L, Yu X, Wang L (2019) Quantitative detection of procalcitonin using an electrochemical immunosensor based on MoO3/Au@rGO nanocomposites. Analyst 144:6968-6974. https://doi.org/10.1039/C9AN01721F

125. Li Y, Liu L, Liu X et al (2020) A dual-mode PCT electrochemical immunosensor with $\mathrm{CuCo} 2 \mathrm{~S} 4$ bimetallic sulfides as enhancer. Biosens Bioelectron 163:112280. https://doi.org/10.1016/J. BIOS.2020.112280

126. Li S, Xing Z, Feng J et al (2021) A sensitive biosensor of CdS sensitized $\mathrm{BiVO} 4 / \mathrm{GaON}$ composite for the photoelectrochemical immunoassay of procalcitonin. Sensors Actuators, B Chem 329:129244. https://doi.org/10.1016/j.snb.2020.129244

127. Wu J, Chen Y, Yang M et al (2017) Streptavidin-biotin-peroxidase nanocomplex-amplified microfluidics immunoassays for simultaneous detection of inflammatory biomarkers. Anal Chim Acta 982:138-147. https://doi.org/10.1016/j.aca.2017.05.031
128. Xu X, Song X, Nie R et al (2019) Ultra-sensitive capillary immunosensor combining porous-layer surface modification and biotin-streptavidin nano-complex signal amplification: application for sensing of procalcitonin in serum. Talanta 205:120089. https://doi.org/10.1016/j.talanta.2019.06.089

129. Nie R, Xu X, Cui X et al (2019) A highly sensitive capillarybased immunosensor by combining with peroxidase nanocomplex-mediated signal amplification for detection of procalcitonin in human serum. ACS Omega 4:6210-6217. https://doi.org/10. 1021/acsomega.9b00249

130. Nie R, Huang J, Xu X, Yang L (2020) A portable pencil-like immunosensor for point-of-care testing of inflammatory biomarkers. Anal Bioanal Chem 412:3231-3239. https://doi.org/ $10.1007 / \mathrm{s} 00216-020-02582-\mathrm{z}$

131. Yang L, Xue J, Jia Y et al (2019) Construction of well-ordered electrochemiluminescence sensing interface using peptidebased specific antibody immobilizer and $\mathrm{N}$-(aminobutyl)-N(ethylisoluminol) functionalized ferritin as signal indicator for procalcitonin analysis. Biosens Bioelectron 142:111562. https:// doi.org/10.1016/j.bios.2019.111562

132. Xu P, Zhang Y, Li X, et al (2020) Electrochemiluminescence immunosensor based on ferrocene functionalized ZIF-8 quenching the electrochemiluminescence of $\mathrm{Ru}(\mathrm{bpy}) 32+$-doped silica nanoparticles embodied N-butyl diethanolamine. Sensors Actuators B Chem 129101.https://doi.org/10.1016/j.snb.2020.129101

133. Fang J, Li J, Feng R et al (2021) Dual-quenching electrochemiluminescence system based on novel acceptor CoOOH@Au NPs for early detection of procalcitonin. Sensors Actuators, B Chem 332:129544. https://doi.org/10.1016/j.snb.2021.129544

134. Bao C, Fan D, Liu X, et al (2019) A signal-off type photoelectrochemical immunosensor for the ultrasensitive detection of procalcitonin: $\mathrm{Ru}$ (bpy)32+ and $\mathrm{Bi} 2 \mathrm{~S} 3$ co-sensitized $\mathrm{ZnTiO} 3 /$ $\mathrm{TiO} 2$ polyhedra as matrix and dual inhibition by $\mathrm{SiO} 2 / \mathrm{PDA}-\mathrm{Au}$. Biosens Bioelectron 142:.https://doi.org/10.1016/j.bios.2019. 111513

135. Leng D, Li J, Xu R et al (2020) THCH as electron donor in controlled-release system for procalcitonin analysis based on Bi2Sn2O7 photoanode. Sensors Actuators, B Chem 321:128509. https://doi.org/10.1016/j.snb.2020.128509

136. Serebrennikova KV, Samsonova JV, Osipov AP et al (2017) Gold nanoflowers and gold nanospheres as labels in lateral flow immunoassay of procalcitonin. Nano Hybrids Compos 13:47-53. https://doi.org/10.4028/www.scientific.net/nhc.13.47

137. Tanak AS, Muthukumar S, Krishnan S et al (2021) Multiplexed cytokine detection using electrochemical point-of-care sensing device towards rapid sepsis endotyping. Biosens Bioelectron 171:112726. https://doi.org/10.1016/j.bios.2020.112726

138. Gentili D, D'Angelo P, Militano F et al (2018) Integration of organic electrochemical transistors and immuno-affinity membranes for label-free detection of interleukin-6 in the physiological concentration range through antibody-antigen recognition. $\mathbf{J}$ Mater Chem B 6:5400-5406. https://doi.org/10.1039/c8tb01697f

139. Sabaté J, Henry OYF, Jolly P, Ingber DE (2019) An antifouling coating that enables affinity-based electrochemical biosensing in complex biological fluids. Nat Nanotechnol 14:1143-1149. https://doi.org/10.1038/s41565-019-0566-Z

140. Aydın EB, Aydın M, Sezgintürk MK (2021) A novel electrochemical immunosensor based on acetylene black/epoxy-substituted-polypyrrole polymer composite for the highly sensitive and selective detection of interleukin 6. Talanta 222:121596. https:// doi.org/10.1016/j.talanta.2020.121596

141. Chandra Barman S, Sharifuzzaman M, Zahed MA et al (2021) A highly selective and stable cationic polyelectrolyte encapsulated black phosphorene based impedimetric immunosensor for interleukin-6 biomarker detection. Biosens Bioelectron 186:113287. https://doi.org/10.1016/j.bios.2021.113287 
142. Chen H, Li J, Zhang X et al (2018) Automated in vivo nanosensing of breath-borne protein biomarkers. Nano Lett 18:47164726. https://doi.org/10.1021/acs.nanolett.8b01070

143. Tertis M, Ionut P, Bogdan D et al (2019) Biosensors and Bioelectronics Impedimetric aptasensor for the label-free and selective detection of Interleukin-6 for colorectal cancer screening. Biosens Bioelectron 137:123-132. https://doi.org/10.1016/j.bios. 2019.05.012

144. Aydın EB (2020) Highly sensitive impedimetric immunosensor for determination of interleukin 6 as a cancer biomarker by using conjugated polymer containing epoxy side groups modified disposable ITO electrode. Talanta 215:120909. https://doi. org/10.1016/j.talanta.2020.120909

145. Militano F, Poerio T, Mazzei R et al (2017) Development of biohybrid immuno-selective membranes for target antigen recognition. Biosens Bioelectron 92:54-60. https://doi.org/ 10.1016/j.bios.2017.02.003

146. Wang Y, Sun J, Hou Y et al (2019) A SERS-based lateral flow assay biosensor for quantitative and ultrasensitive detection of interleukin-6 in unprocessed whole blood. Biosens Bioelectron 141:111432. https://doi.org/10.1016/j.bios.2019.111432

147. Hao Z, Pan Y, Shao W et al (2019) Graphene-based fully integrated portable nanosensing system for on-line detection of cytokine biomarkers in saliva. Biosens Bioelectron 134:16-23. https://doi.org/10.1016/j.bios.2019.03.053

148. Approach I (2021) Detection of an IL-6 biomarker using a GFET platform developed with a facile organic solvent-free aptamer

149. Khosravi F, Loeian SM, Panchapakesan B (2017) Ultrasensitive label-free sensing of IL-6 based on PASE functionalized carbon nanotube micro-arrays with RNA-aptamers as molecular recognition elements. Biosensors 7:.https://doi.org/10.3390/bios7020017

150. Muhammad M, Shaosheng C, Huang Q (2021) Aptamer-functionalized Au nanoparticles array as the effective SERS biosensor for label-free detection of interleukin-6 in serum. Sensors Actuators, B Chem 334:129607. https://doi.org/10.1016/j.snb. 2021.129607

151. Aray A, Chiavaioli F, Arjmand M et al (2016) SPR-based plastic optical fibre biosensor for the detection of C-reactive protein in serum. J Biophotonics 9:1077-1084. https://doi.org/10.1002/ jbio. 201500315

152. Matsuura R, Tawa K, Kitayama Y, Takeuchi T (2016) A plasmonic chip-based bio/chemical hybrid sensing system for the highly sensitive detection of C-reactive protein. Chem Commun 52:3883-3886. https://doi.org/10.1039/c5cc07868g

153. Wang W, Mai Z, Chen $Y$ et al (2017) A label-free fiber optic SPR biosensor for specific detection of C-reactive protein. Sci Rep 7:1-8. https://doi.org/10.1038/s41598-017-17276-3

154. Walter J-G, Eilers A, Alwis LSM et al (2020) SPR biosensor based on polymer multi-mode optical waveguide and nanoparticle signal enhancement. Sensors 2020 20:2889. https://doi.org/ $10.3390 /$ S20102889

155. Koukouvinos G, Petrou P, Misiakos K et al (2016) Simultaneous determination of CRP and D-dimer in human blood plasma samples with white light reflectance spectroscopy. Biosens Bioelectron 84:89-96. https://doi.org/10.1016/j.bios.2015.11.094

156. Wu B, Chen N, Wang Q et al (2016) A simple label-free aptamerbased method for C-reactive protein detection. Anal Methods 8:4177-4180. https://doi.org/10.1039/c6ay01007e

157. Belushkin A, Yesilkoy F, Altug H (2018) Nanoparticle-enhanced plasmonic biosensor for digital biomarker detection in a microarray. ACS Nano 12:4453-4461. https://doi.org/10.1021/acsnano. 8 b00519

158. Kim SW, Cho IH, Lim GS et al (2017) Biochemical-immunological hybrid biosensor based on two-dimensional chromatography for on-site sepsis diagnosis. Biosens Bioelectron 98:7-14. https:// doi.org/10.1016/j.bios.2017.06.032

159. Zhang X, Hu R, Zhang K et al (2016) An ultrasensitive label-free immunoassay for C-reactive protein detection in human serum based on electron transfer. Anal Methods 8:6202-6207. https:// doi.org/10.1039/c6ay01464j

160. Thangamuthu M, Santschi C, Martin OJF (2018) Label-free electrochemical immunoassay for C-reactive protein. Biosensors 8:34. https://doi.org/10.3390/bios8020034

161. Liu TZ, Hu R, Liu Y, et al (2020) Amperometric immunosensor based on covalent organic frameworks and $\mathrm{Pt} / \mathrm{Ru} / \mathrm{C}$ nanoparticles for the quantification of C-reactive protein. Microchim Acta 187:.https://doi.org/10.1007/s00604-020-04286-8

162. Vilian ATE, Kim W, Park B et al (2019) Efficient electron-mediated electrochemical biosensor of gold wire for the rapid detection of C-reactive protein: a predictive strategy for heart failure. Biosens Bioelectron 142:111549. https://doi.org/10.1016/j.bios. 2019.111549

163. Molinero-Fernández Á, Moreno-Guzmán M, López MÁ, Escarpa A (2020) An array-based electrochemical magneto-immunosensor for early neonatal sepsis diagnostic: fast and accurate determination of C-reactive protein in whole blood and plasma samples. Microchem J 157:104913. https://doi.org/10.1016/j.microc. 2020.104913

164. Boonkaew S, Chaiyo S, Jampasa S et al (2019) An origami paperbased electrochemical immunoassay for the C-reactive protein using a screen-printed carbon electrode modified with graphene and gold nanoparticles. Microchim Acta 186:1-10. https://doi. org/10.1007/s00604-019-3245-8

165. Kuo YC, Lee CK, Lin CT (2018) Improving sensitivity of a miniaturized label-free electrochemical biosensor using zigzag electrodes. Biosens Bioelectron 103:130-137. https://doi.org/10. 1016/J.BIOS.2017.11.065

166. Yagati AK, Pyun JC, Min J, Cho S (2016) Label-free and direct detection of C-reactive protein using reduced graphene oxidenanoparticle hybrid impedimetric sensor. Bioelectrochemistry 107:37-44. https://doi.org/10.1016/j.bioelechem.2015.10.002

167. Magliulo M, De Tullio D, Vikholm-Lundin I et al (2016) Labelfree C-reactive protein electronic detection with an electrolyte-gated organic field-effect transistor-based immunosensor. Anal Bioanal Chem 408:3943-3952. https://doi.org/10.1007/ s00216-016-9502-3

168. Boonyasit Y, Chailapakul O, Laiwattanapaisal W (2019) A folding affinity paper-based electrochemical impedance device for cardiovascular risk assessment. Biosens Bioelectron 130:389396. https://doi.org/10.1016/j.bios.2018.09.031

169. Jarczewska M, Rębiś J, Górski Ł, Malinowska E (2018) Development of DNA aptamer-based sensor for electrochemical detection of C-reactive protein. Talanta 189:45-54. https://doi.org/10. 1016/j.talanta.2018.06.035

170. Sarangadharan I, Hsu C-P, Chu C-H et al (2017) Blood based biomarker detection using FET biosensor: towards self-health management. ECS Trans 77:11-15. https://doi.org/10.1149/ 07707.0011ecst

171. Tsai MZ, Te HC, Chen Y et al (2018) Real-time CRP detection from whole blood using micropost-embedded microfluidic chip incorporated with label-free biosensor. Analyst 143:503-510. https://doi.org/10.1039/c7an01374d

172. Ouyang M, Di Carlo D (2019) Nanoplasmonic swarm biosensing using single nanoparticle colorimetry. Biosens Bioelectron 132:162-170. https://doi.org/10.1016/j.bios.2019.02.056

173. Sinha A, Tai TY, Li KH et al (2019) An integrated microfluidic system with field-effect-transistor sensor arrays for detecting multiple cardiovascular biomarkers from clinical samples. Biosens Bioelectron 129:155-163. https://doi.org/10.1016/j.bios. 2019.01.001 
174. Lee SH, Choi S, Kwon K et al (2017) A photothermal biosensor for detection of C-reactive protein in human saliva. Sensors Actuators, B Chem 246:471-476. https://doi.org/10.1016/j.snb. 2017.01.188

175. Lee HH, Bae M, Jo SH et al (2016) Differential-mode HEMTbased biosensor for real-time and label-free detection of C-reactive protein. Sensors Actuators, B Chem 234:316-323. https:// doi.org/10.1016/j.snb.2016.04.117

176. James-Pemberton P, Łapińska U, Helliwell M et al (2020) Accuracy and precision analysis for a biophotonic assay of C-reactive protein. Analyst 145:2751-2757. https://doi.org/10.1039/c9an02516b

177. Yang Z, Liu Y, Lei C et al (2015) A flexible giant magnetoimpedance-based biosensor for the determination of the biomarker C-reactive protein. Microchim Acta 182:2411-2417. https://doi. org/10.1007/s00604-015-1587-4

178. Zheng W, Yao L, Teng J et al (2018) Lateral flow test for visual detection of multiple microRNAs. Sensors Actuators, B Chem 264:320-326. https://doi.org/10.1016/j.snb.2018.02.159

179. Roy S, Soh JH, Ying JY (2016) A microarray platform for detecting disease-specific circulating miRNA in human serum. Biosens Bioelectron 75:238-246. https://doi.org/10.1016/j.bios.2015.08.039

180. Hwu S, Blickenstorfer Y, Tiefenauer RF et al (2019) Dark-field microwells toward high-throughput direct miRNA sensing with gold nanoparticles. ACS Sensors 4:1950-1956. https://doi.org/ 10.1021/acssensors.9b00946

181. Cai J, Ding L, Gong P, Huang J (2020) A colorimetric detection of microRNA-148a in gastric cancer by gold nanoparticle-RNA conjugates. Nanotechnology 31:.https://doi.org/10.1088/1361-6528/ab55b7

182. Ki J, Lee HY, Son HY et al (2019) Sensitive plasmonic detection of miR-10b in biological samples using enzyme-assisted target recycling and developed LSPR probe. ACS Appl Mater Interfaces 11:18923-18929. https://doi.org/10.1021/acsami.9b03005
183. Huang J, Shangguan J, Guo Q et al (2019) Colorimetric and fluorescent dual-mode detection of microRNA based on duplexspecific nuclease assisted gold nanoparticle amplification. Analyst 144:4917-4924. https://doi.org/10.1039/c9an01013k

184. Wang Y, Zhang L, Cui K et al (2019) Paper-supported self-powered system based on a glucose/O 2 biofuel cell for visual microRNA-21 sensing. ACS Appl Mater Interfaces 11:5114-5122. https://doi.org/10.1021/acsami.8b20034

185. Su S, Sun Q, Ma J et al (2020) Ultrasensitive analysis of microRNAs with gold nanoparticle-decorated molybdenum disulfide nanohybrid-based multilayer nanoprobes. Chem Commun 56:9012-9015. https://doi.org/10.1039/d0cc03845h

186. Zhang P, Li Z, Wang $\mathrm{H}$ et al (2017) DNA nanomachine-based regenerated sensing platform: a novel electrochemiluminescence resonance energy transfer strategy for ultra-high sensitive detection of microRNA from cancer cells. Nanoscale 9:2310-2316. https://doi.org/10.1039/C6NR08631D

187. Yu Y, Chen Z, Shi L et al (2014) Ultrasensitive electrochemical detection of microRNA based on an arched probe mediated isothermal exponential amplification. Anal Chem 86:8200-8205. https://doi.org/10.1021/AC501505A/SUPPL_FILE/AC501 505A_SI_001.PDF

188. Azzouzi S, Fredj Z, Turner APF et al (2019) Generic neutravidin biosensor for simultaneous multiplex detection of microRNAs via electrochemically encoded responsive nanolabels. ACS Sensors 4:326-334. https://doi.org/10.1021/acssensors.8b00942

Publisher's Note Springer Nature remains neutral with regard to jurisdictional claims in published maps and institutional affiliations. 